\title{
Erosion Vulnerability Assessment of Sperchios River Basin, in East Central Greece-A GIS Based Analysis
}

\author{
Nikolaos Stathopoulos ${ }^{1}$, Evdoxia Lykoudi', Eleni Vasileiou', Dimitrios ${ }^{1}{ }^{1}{ }^{1}{ }^{1}{ }^{1}$, \\ Dimitrios Dimitrakopoulos ${ }^{2}$
}

\footnotetext{
${ }^{1}$ Department of Geological Sciences, School of Mining Engineering and Metallurgy, National Technical University of Athens, Athens, Greece

${ }^{2}$ Department of Hydrogeological Studies, Direction of Studies and Development of Mines, Public Power Corporation of Greece, Athens, Greece

Email: `nstath@metal.ntua.gr, elykoudi@metal.ntua.gr, elvas@metal.ntua.gr, rozos@metal.ntua.gr, ddimitrakopoulos@gmail.com
}

How to cite this paper: Stathopoulos, N., Lykoudi, E., Vasileiou, E., Rozos, D. and Dimitrakopoulos, D. (2017) Erosion Vulnerability Assessment of Sperchios River Basin, in East Central Greece-A GIS Based Analysis. Open Journal of Geology, 7, 621-646. https://doi.org/10.4236/ojg.2017.75043

Received: April 12, 2017

Accepted: May 9, 2017

Published: May 12, 2017

Copyright $\odot 2017$ by authors and Scientific Research Publishing Inc. This work is licensed under the Creative Commons Attribution International License (CC BY 4.0).

http://creativecommons.org/licenses/by/4.0/

\begin{abstract}
One of the most important natural processes, with significant environmental impacts, is soil erosion. The aim of this paper is to evaluate and assess the erosion vulnerability of the geological formations constituting Sperchios River basin, in Eastern Central Greece, as well as to distinguish and locate the areas of such risk and estimate it. The developed methodology in this paper is based on Multi-Criteria Evaluation (MCE), with the implementation of Weighted Cartographic Overlay (WCO) technique in Geographic Information Systems (GIS) environment. By applying this method, an attempt was made to combine a set of factors, such as geological-hydrogeological characteristics, morphological slopes and hydrographic texture (causative factors of the phenomenon) along with rainfall (triggering factor) and land cover/use (competitive factor). The weighted combination of these factors defines the vulnerability of the formations in the area of interest. The main results of the methodology are two thematic maps of erosion vulnerability of Sperchios basin's formations, one that does not include land use/cover factor and one with current existing conditions of the basin (co-evaluating land use/cover). In the first case, 36\% of the basin surface undergoes high erosion vulnerability, while $53 \%$ present medium vulnerability. These percentages reduced significantly in the second case (3\% is the high erosion vulnerability category and $38 \%$ the medium one), fact that proves the importance of vegetation in erosion restriction and protection of the geological formations consisting the Sperchios River basin.
\end{abstract}

\section{Keywords}

Erosion Vulnerability, Sperchios River Basin, Geographical Information 
Systems, Multi-Criteria Evaluation

\section{Introduction}

Soil erosion is a natural process, with significant environmental impacts. This natural process constitutes one of the main environmental problems affecting Sperchios River basin in Eastern Central Greece, causing soil degradation and augmentation of sediment yield in the river. The high rate of sediment transport in the river system causes unique changes of the deltaic part and shoreline throughout Greece. Vulnerability assessment and mapping of erosion are of high importance for managing a hydrological basin and constitute useful tools for environmental planning.

Many methods and models are used to assess and analyze this process, both quantitatively and qualitatively. The RUSLE (Revised Universal Soil Loss Equation) is considered as a simple model for predicting soil erosion [1]. It is a model that is an evolution of the Universal Soil Loss Equation (USLE) model, as it considers upstream areas contributing to downstream surface runoff. Thus it is a model with better predictability than the USLE. In this regard, the topographic parameter gains a more grounded scientific connotation, physically improving the previous approach [2].

In general, the previous methods are used in arable lands with low terrain slopes and mostly in small basins.

From a more qualitative aspect, analysis of spatial information is becoming an emerging approach which is capable of acquiring, managing and analyzing complex problems of river basins and lake watersheds. In recent years, GIS have proven to be a good alternative to serve as a better decision support tool in planning, management and sustainable development of soil and water resources. Consequently, the integration of multi-criteria evaluation (MCE) within a GIS context could help the relevant authorities to improve decision making processes.

The main purpose of the MCE technique is to investigate a number of alternatives in the light of multiple criteria and conflicting objectives [3]. In the last decade, MCE has received renewed attention in the context of GIS-based decision making [4] [5] [6]. Different studies have been conducted using MCE technique in the area of the natural resources management [7]-[12].

In this paper, an attempt is made on spatial estimation of soil erosion in large mountainous catchments of Mediterranean type like Sperchios River, using the MCE method. For this purpose, an evaluation based on GIS was adopted. The applied methodology comprises qualitative analysis. The application of MCE in Sperchios River catchment, aiming at spatial vulnerability assessment of the geological formations, offers in addition valuable assessment of the expected spatial distribution of soil erosion.

Thus, in order to evaluate and assess the erosion vulnerability of the geological 
formations in a region like Sperchios River basin as well as to distinguish the areas of high erosion vulnerability is of high importance. The main factors that control erosion are the lithological composition of the geological formations, along with morphology and hydrographic network texture of the study site. The combination of these factors defines the vulnerability of the formations.

This paper is based on the methodology presented by [13] and later by [14], with specific modifications that were considered to be appropriate in this implementation. In particular, the rainfall factor was co-evaluated in the erosion model and weights were assigned in each factor during the phase of synthesis, according to bibliography and experts' opinions. The development of this method offers a more effective and integrated approach in erosion vulnerability research. Conclusively, the methodology developed in this paper is based on multi-criteria evaluation (MCE), with the implementation of Weighted Cartographic Overlay (WCO) technique in Geographic Information System environment. This method combines a set of factors, such as geological characteristics, morphological slopes, hydrographic network, along with rainfall and land cover/use which are the causative, triggering and competitive factors respectively (Figure 1). The weighted combination of these factors defines the vulnerability of the formations in the study area and is indicated generally as a primary estimation method for their vulnerability, as it can easily be adjusted based on the updated data of every new simulation.

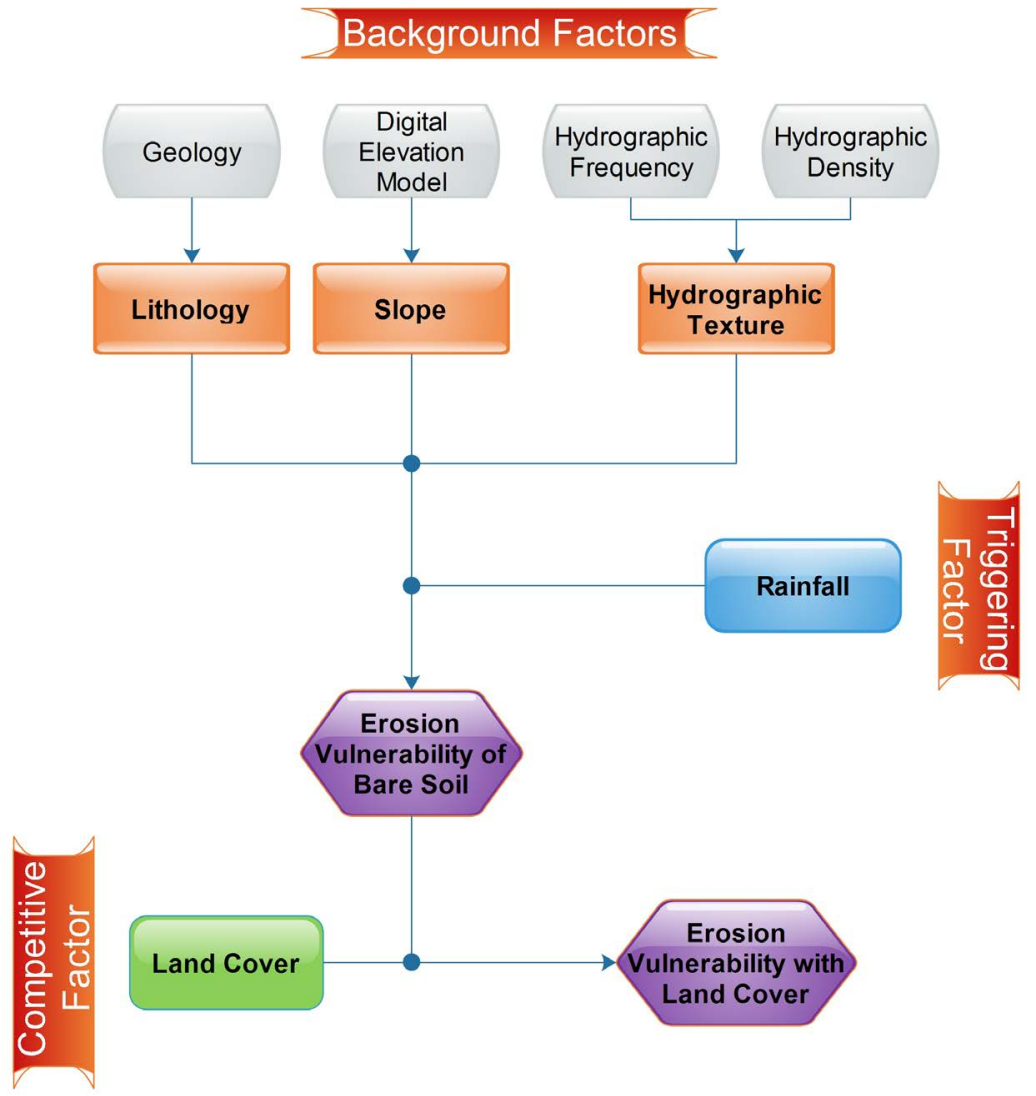

Figure 1. Flowchart of the methodology. 
The results derived from this attempt provide important and very useful information for the behavior of geological formations under the current conditions of Sperchios basin (with the existing vegetation setting), as well as for the behavior of geological formations under extreme events and unfavorable circumstances such as fire, deforestation, and other natural disasters. In order to accomplish this purpose, two thematic maps were produced, one combining all the factors of the analysis along with land cover/use depicting thus the current condition of the basin and one excluding the land cover/use factor i.e. simulating the worst case scenario for the basin. Therefore, MCE seems to be applicable to GIS-based spatial delineation of erosion vulnerability, which helps to assess the most erosion prone areas in Sperchios River Basin, especially on mountainous and semi-mountainous zones.

\section{Material and Methods}

\subsection{Geomorphological Conditions of the Study Area}

Sperchios river basin (Figure 2) extends in the northern part of Eastern Central Greece Water Compartment and is surrounded by Orthris Mountain (1727 m) from North, by Vardousia $(2437 \mathrm{~m})$, Oiti $(2152 \mathrm{~m})$ and Kalidromo (1372 m) mountains from South, and by Timfristos Mountain $(2316 \mathrm{~m})$ from the west. The runoff of Sperchios River ends up in Maliakos Gulf, the coastline of which is the eastern limit of Sperchios basin. This basin occupies an area of $2031 \mathrm{~km}^{2}$

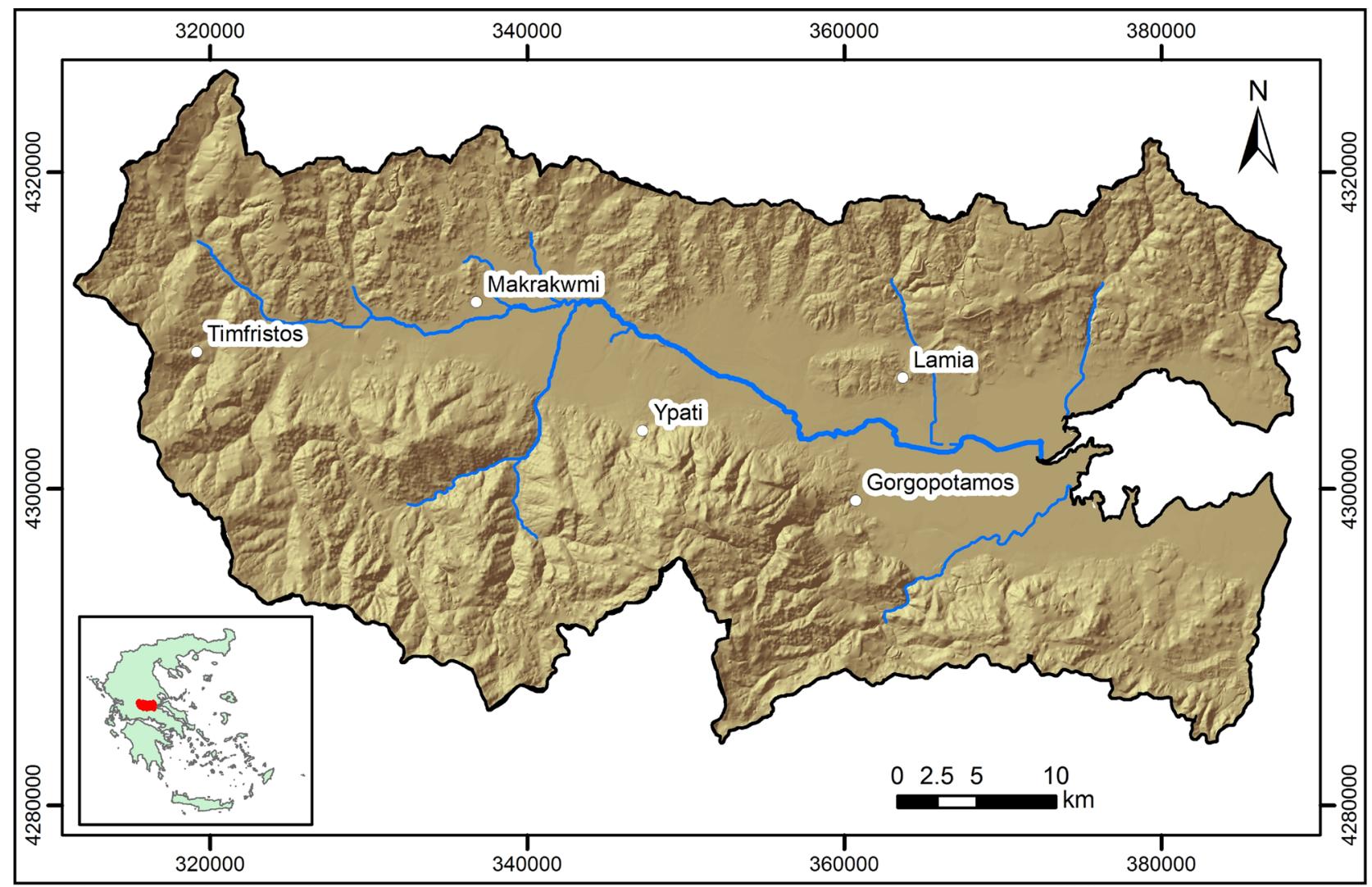

Figure 2. Hydrological basin of Sperchios River. 
with an average altitude of $605 \mathrm{~m}$. Sperchios riverbed is recharged by many streams of permanent and periodic flow. The high gradients, which are present along with almost the $2 / 3$ of the total length of the river course, form a rather mountainous-streamy topography, with crucial flooding peaks and very intense sediment yield. On the contrary, within the last downstream part of its course, the river is transformed gradually into a lowland relief, where cases of severe flooding have been recorded. The deltaic alluvial part of the valley covers about $200 \mathrm{~km}^{2}$ and is continuously forming with a unique rate throughout Greece. This rate, according to [15], was estimated approximately in 130 acres annually, with augmentation trends in the last 150 - 200 years.

The morphology of the area is particularly steep in the south part of the basin, while in the north part is gentler and with lower elevations. The largest part of the area $\left(767 \mathrm{~km}^{2}\right)$ is characterized by medium to high morphological slopes i.e. from $12 \%$ to $35 \%$. Slopes lower than $12 \%$ as well as higher than $35 \%$, are observed in equally large areas covering $690 \mathrm{~km}^{2}$ and $539 \mathrm{~km}^{2}$ respectively. Furthermore it should be stressed that the southwestern area of the basin exhibits the higher morphological slope inclination $(>35 \%)$, while almost the whole riverbed flows through a $42 \mathrm{~km}^{2}$ lowland part. The Valley of Sperchios River varies in width from 2 up to $13 \mathrm{~km}$, throughout a distance of approximately $50 \mathrm{~km}$ up to Maliakos Gulf.

The type of the hydrographic network is characterized in general as elongated dendritic and Sperchios as a 7th class river. Furthermore, asymmetry is observed in the basin, almost exclusively due to its neotectonic as well as lithological structure.

The river course has shifted many times, but its riverbed and delta still remains in the south part of the valley depositing high volumes of sediments. The overflow channel created in 1957, north of today's riverbed, has created (due to sediment deposit) a wide shallow area in the northwest part of Maliakos Gulf [16].

Regarding the geological conditions (Figure 3), the main rocks that constitute Sperchios valley are igneous and sedimentary [17]-[24]. Analytically, the main geological formations in the west part of the basin are limestones, flysch and clastic sediments. In the north, northeast and southeast parts of the basin, and specifically in Kallidromo Mountain, the main rocks are limestone and schist-crests with ophiolites. In the south part (Oiti mountain), prevailing geological formations are limestones and, in a limited extent, flysch formations.

Finally, the lower parts of Sperchios River valley are covered by quaternary deposits, which constitute the $20 \%$ of the basin's extent. These sediments consist of conglomerates, lacustrine deposits, quaternary alluvial deposits, scree, talus cones, as well as Holocene alluvial deposits.

Sperchios River basin, as well as Maliakos Gulf, constitutes an asymmetric tectonic rift.

\subsection{Data-Spatial Database}

The main objective of this study, as mentioned before, is the application of MCE 


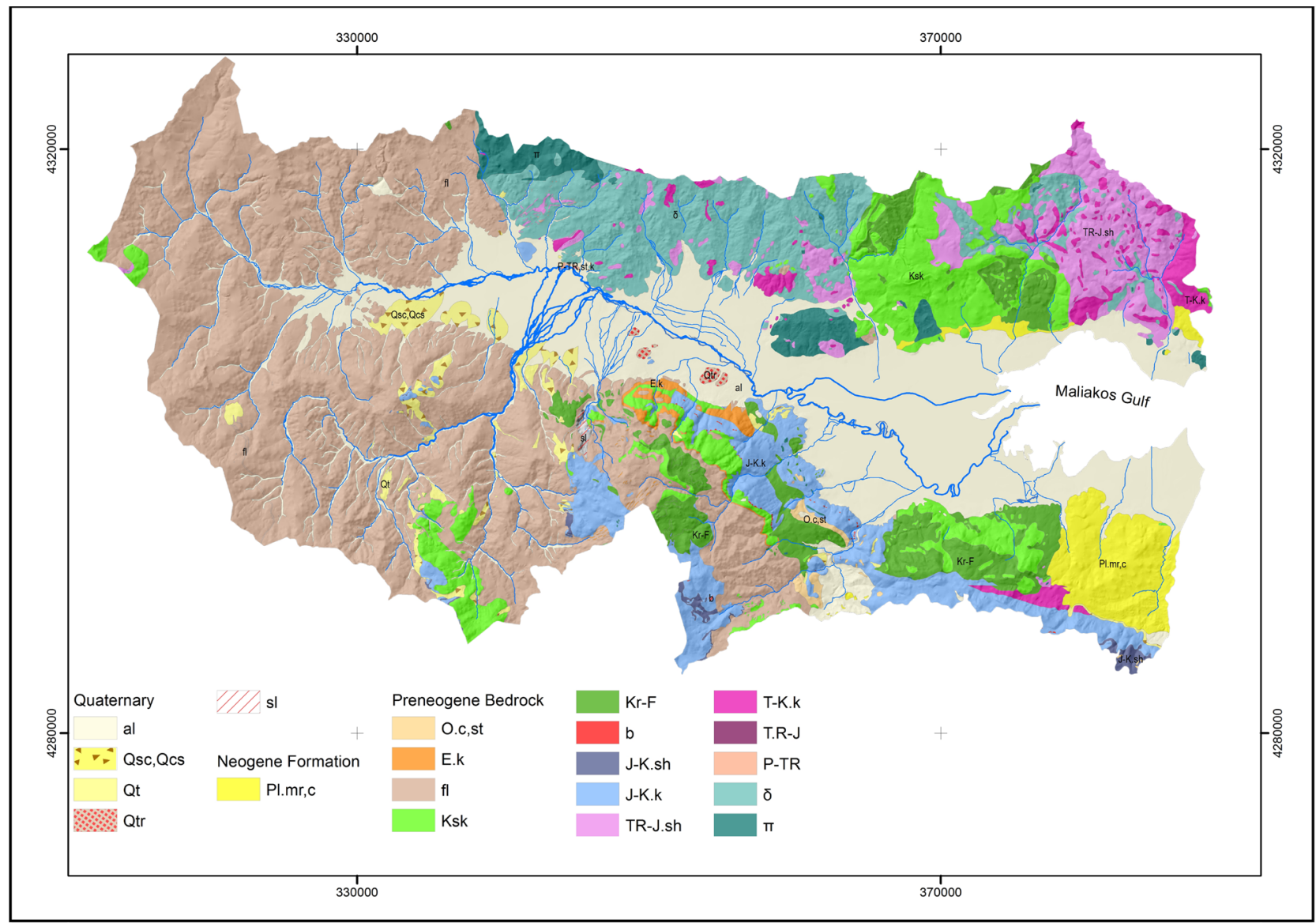

\begin{tabular}{|l|l|l|}
\hline al: Alluvial deposits & $\begin{array}{l}\text { fl: Flysch (sandstones, graywackes, } \\
\text { conglomerates, marls) }\end{array}$ & $\begin{array}{l}\text { T-K.k: Dolomite and limestone } \\
\text { (Triassic-Jurassic) }\end{array}$ \\
\hline Qsc, Qcs: Talus cones and scree & Kr-F: Upper-cretaceous Flysch & T.R-J: Radiolarite (Triassic-Jurassic) \\
\hline Qt: Fluvial terraces & $\begin{array}{l}\text { Ksk: Upper-cretaceous transgressive } \\
\text { limestones }\end{array}$ & $\begin{array}{l}\text { P-TR: Schists, Sandstones, Limestones } \\
\text { (Upper Permio Lower Triassic }\end{array}$ \\
\hline Qtr: Terra Rossa & b: Bauxite & OI: Ophiolite: \\
\hline $\begin{array}{l}\text { PI.mr,c: Neogene Formation } \\
\text { (marls, conglomerates etc) }\end{array}$ & $\begin{array}{l}\text { J-K.k: Limestones } \\
\text { (Jurassic-Lower Cretaceous) }\end{array}$ & $\begin{array}{l}\text { ठ: Diabas-Dolerite. Tuffs of igneous } \\
\text { basic rocks }\end{array}$ \\
\hline $\begin{array}{l}\text { O.c,st: Molassik sediments } \\
\text { J-K.sh: Shale-Sandstone-cherty } \\
\text { formation (Jurassic) }\end{array}$ & T: Peridotite \\
\hline $\begin{array}{l}\text { E.k: Thinly bedded limestones } \\
\text { (Eocene) }\end{array}$ & $\begin{array}{l}\text { TR-J.sh: Shales-cherts group with } \\
\text { ophoplites (Up Triassic-Jurassic) }\end{array}$ & SI: Landslides \\
\hline
\end{tabular}

Figure 3. Geology of Sperchios River basin.

method in Sperchios River basin aiming at the spatial vulnerability assessment of the geological formations and consequently the expected spatial distribution of soil erosion. The application of MCE technique produces as a final result an "Erosion vulnerability map" This map shows the differentiation of the factors (lithology, geomorphology, hydrology and vegetation) in the basin, namely the variation of the sub-basins based on the erosion susceptibility of their formations. 
For implementing the methodology of this study, in order to research the erosion vulnerability of the area, various data were collected, evaluated and also created, developing thus a spatial database, described below:

- Digital Elevation Model (DEM) with pixel size $25 \times 25 \mathrm{~m}$

- Digital point shapefiles, concerning the names of the towns

- Digital polyline shapefiles, concerning the hydrographic network

- Digital polygon shapefiles, concerning the basin's extent and limits, geological formations and land cover/use

- Tables with descriptive attributes of the above features

- Coordinates of the meteorological stations inside the basin

- Time series of rainfall values (measured by the meteorological stations). The data were derived from the following sources:

- Topographical maps 1:50000, from G.Y.S (Hellenic Military Geographical Service)

- Geological maps 1:50000, from I.G.M.E. (Institute of Geology \& Mineral Exploration)

- Aster SRTM project (DEM)

- Corine 2000 project (Land Use/Cover)

- E.M.Y (Hellenic National Meteorological Service).

The new features that were created after the spatial data analysis, for the study area, are layers concerning lithology, slope, hydrographic density, frequency and texture, rainfall distribution and land cover:

By co-evaluating the above layers the following were produced:

- Erosion Vulnerability without Land Cover

- Erosion Vulnerability with Land Cover

The Coordinate Reference System used for data processing and model analysis is EGSA '87 (Greek Grid).

\subsection{Model Analysis}

\subsubsection{Geology Factor (L)}

In order to assess the effect of geology in the model an "Erosion vulnerability map of lithological formations" was compiled (Figure 4). For the compilation of this map, a number of geological characteristics were co-evaluated, such as lithology, faults, infiltration and permeability of the geological formations in the study area. Formations were classified in three erosion vulnerability classes according to lithological and hydro-lithological characteristics. The geological and hydrogeological data were evaluated based on bibliography.

Formations with high infiltration, such as carbonate rocks which are fractured and so highly karstified and with discontinuities and cracks, as well as formations with low infiltration, such as schists, are of low erosion vulnerability. On the other hand, formations with medium infiltration rates, such as Neogene sediments and the weathering mantle, can become saturated by long-term rainfalls and thus loosen and erode easily [25].

Accordingly, formations of high permeability, such as karstic formations, 


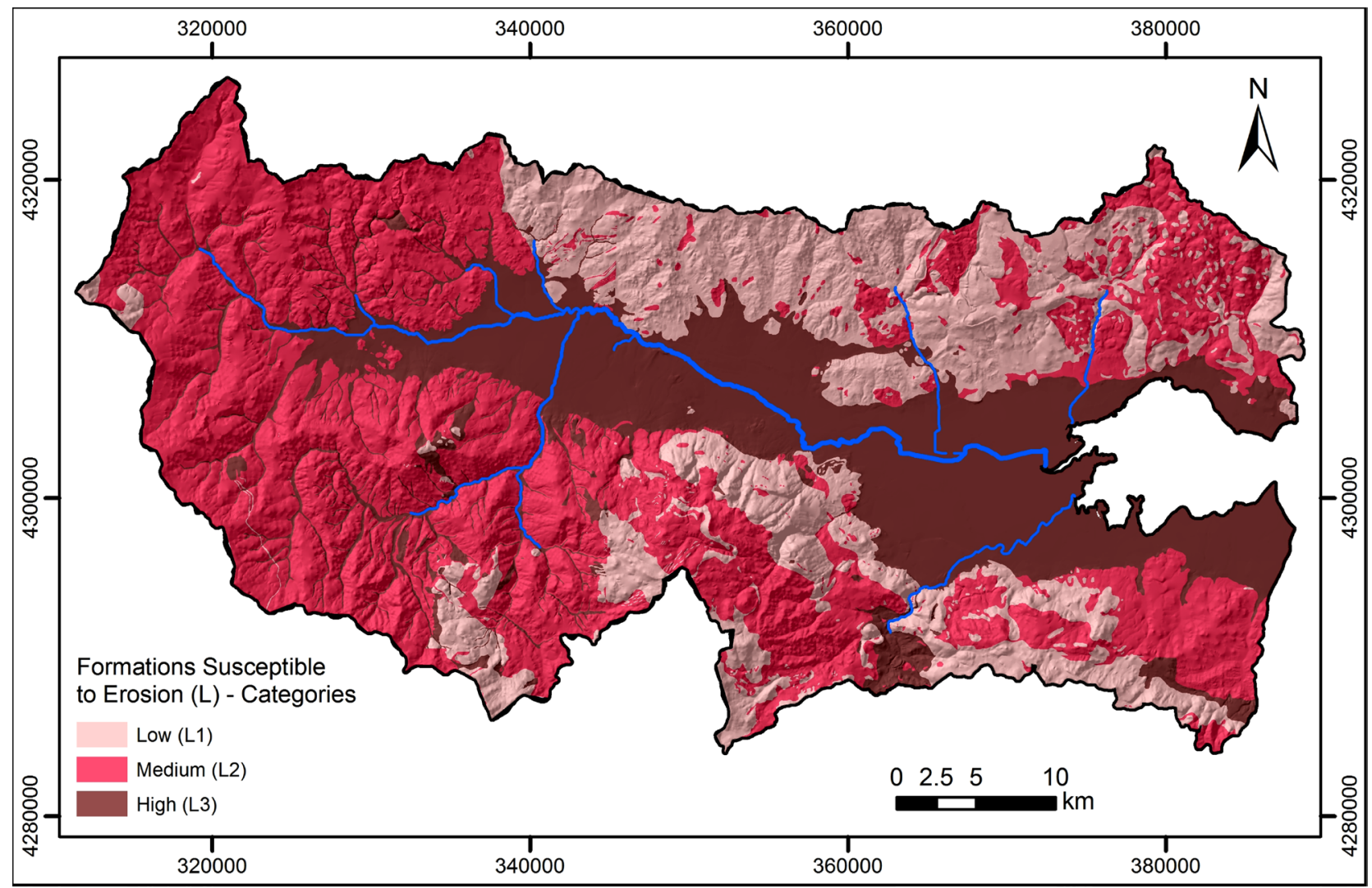

Figure 4. Classified map of the formations based on their erosion susceptibility.

exhibit high infiltration rates about $30 \%-40 \%$ and low surficial runoff resulting in low erosion susceptibility. On the contrary, formations with increased surficial runoff, e.g. schists or Neogene sediments, exhibit higher erosion vulnerability.

The map was synthesized by lithological, hydrolithological and hydrogeological information for the geological formations of the study area and constitutes a "Map of areas with lithological composition susceptible to erosion (L)".

In Figure 4, three geological formation categories are distinguished. Category L1 includes relatively parent formations of low mass or without weathered mantle, as well as formations with high infiltration rates and of high or medium permeability, e.g. limestone, dolomite, etc. L2 includes erodible formations with high infiltration rates and low permeability, as well as those covered by weathered mantle of considerable thickness, e.g. flysch, schist, marl, sandstone, etc. Finally, L3 includes loose and more prone to erosion formations, e.g. silts, sales, alluvial deposits, scree, etc.

\subsubsection{Slope Factor (S)}

In the second map (Figure 5) the morphological slopes ( $S$ ) of the study area were classified. The "Map of morphological slopes (S)" was produced by analyzing the Digital Elevation Model (pixel size $25 \mathrm{~m}$ ). Three categories were created based on the slope values (Figure 5). Category S1 includes sites with slope inclination percentages lower than $12 \%$, S2 sites with slope inclination percentages between $12 \%$ - 35\% and S3 values higher than 35\%. 
The surface extent of the three categories can be seen in Figure 6. S1 category occupies $689.4 \mathrm{~km}^{2}$, namely the $34 \%$ of the whole surface of Sperchios basin, S2 corresponds to $767.1 \mathrm{~km}^{2}$, i.e. $37.9 \%$ of the basin's surface and finally S3 covers $568.8 \mathrm{~km}^{2}$, i.e. $28.1 \%$ of the basin's surface.

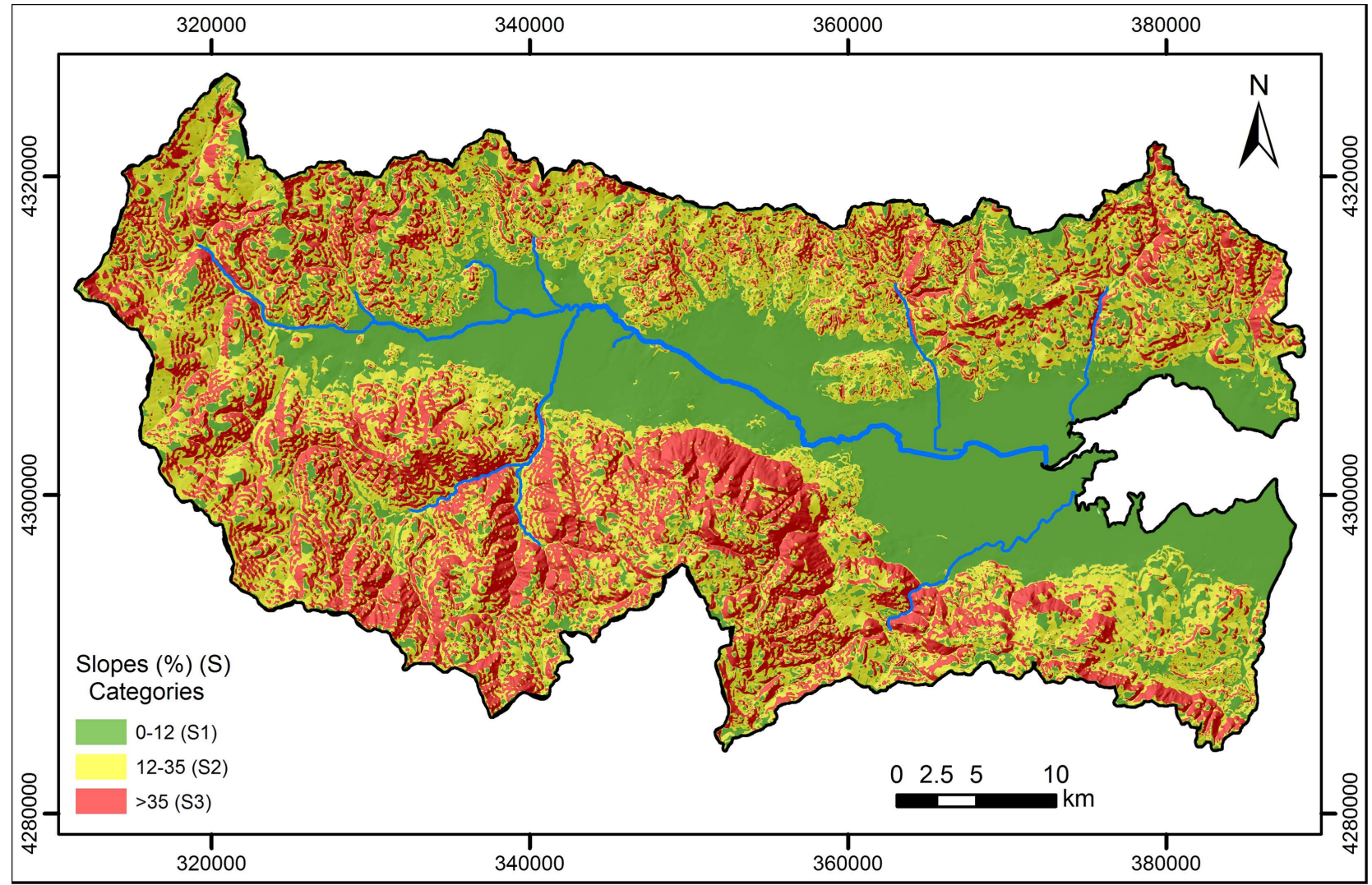

Figure 5. Classified map of the area based on morphological slopes.

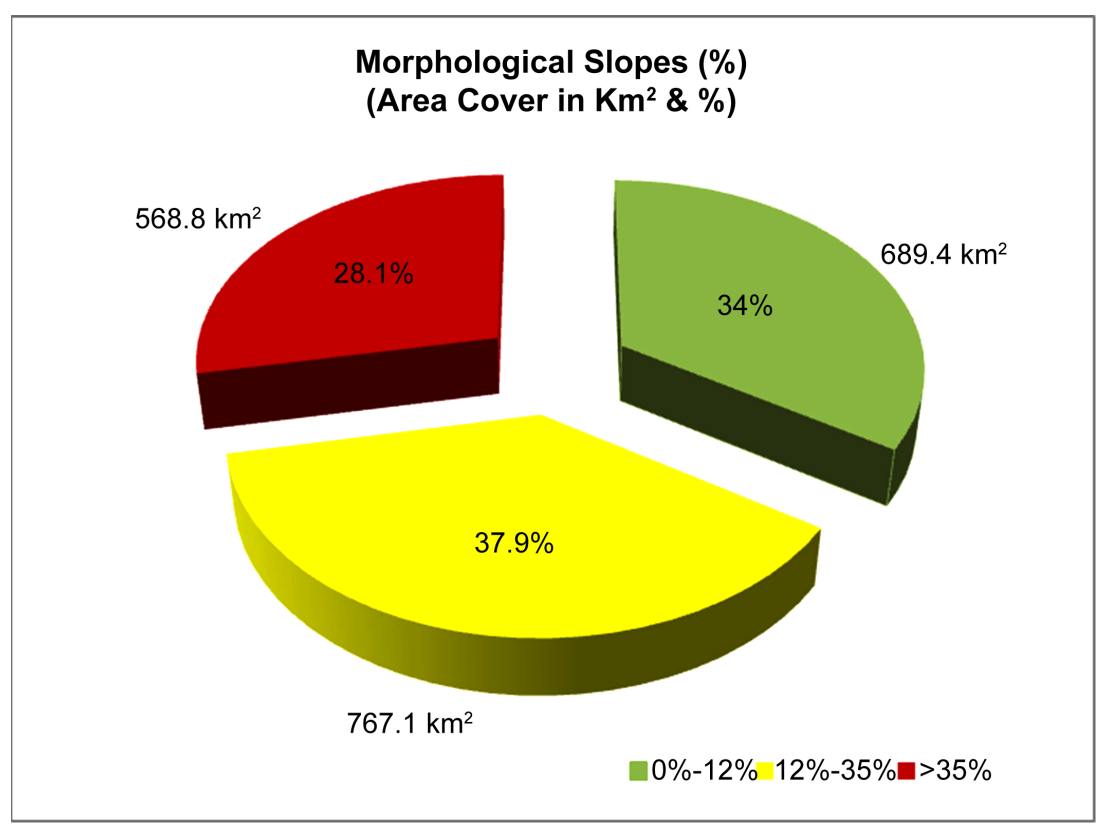

Figure 6. Morphological slopes of the area in $\mathrm{km}^{2}$ and percentages (\%). 
The inclination with percentage from 0 to 12 corresponds to slopes consisting of scree, which are created in high and continuous flow conditions, while the upper limit (12\%) is considered to be the slope limit of stable deposition. Consequently, the erosion processes are milder in sites with lower inclination values and higher in sites with increased inclination i.e. more than $12 \%$ [25].

\subsubsection{Hydrographic Texture Factor (T)}

The third group of maps (Figures 7-9) refers to hydrographic texture analysis of the basin (T), which is expressed by the morphometric parameters of hydrographic density (Dd) and hydrographic frequency (Fs). In order to compile these maps, the classes of the river's branches (channel networks) and of sub basins were calculated, as well as the number and the total length of the river's branches for every sub-basin class.

The drainage density and stream frequency are given in Table 1, according to [26] [27]. Drainage density (Dd) is the ratio of total channel segment lengths, cumulated for all orders within a basin, to the basin area, which is expressed in terms of $\mathrm{km} / \mathrm{sq} \cdot \mathrm{km}[26]$. Stream frequency or channel frequency (Fs) is the total number of stream segments of all orders per unit area [26].

On the next step, the sub-basins were classified in 3 categories according to hydrographic density and frequency, namely high, medium, low, with designations D1, D2, D3 (Figure 7) and F1, F2, F3 (Figure 8) accordingly.

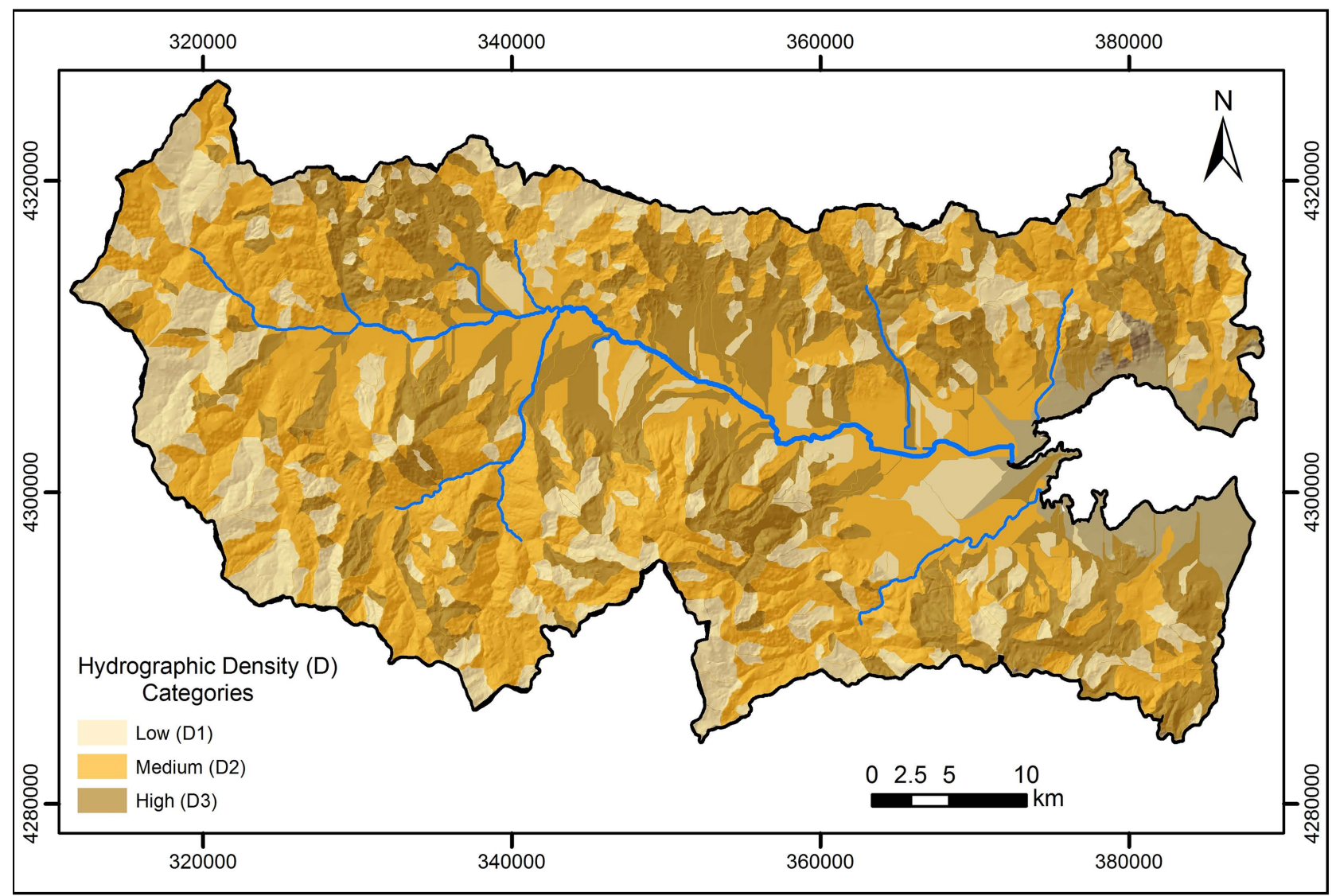

Figure 7. Classification map of the study area based on hydrographic density. 


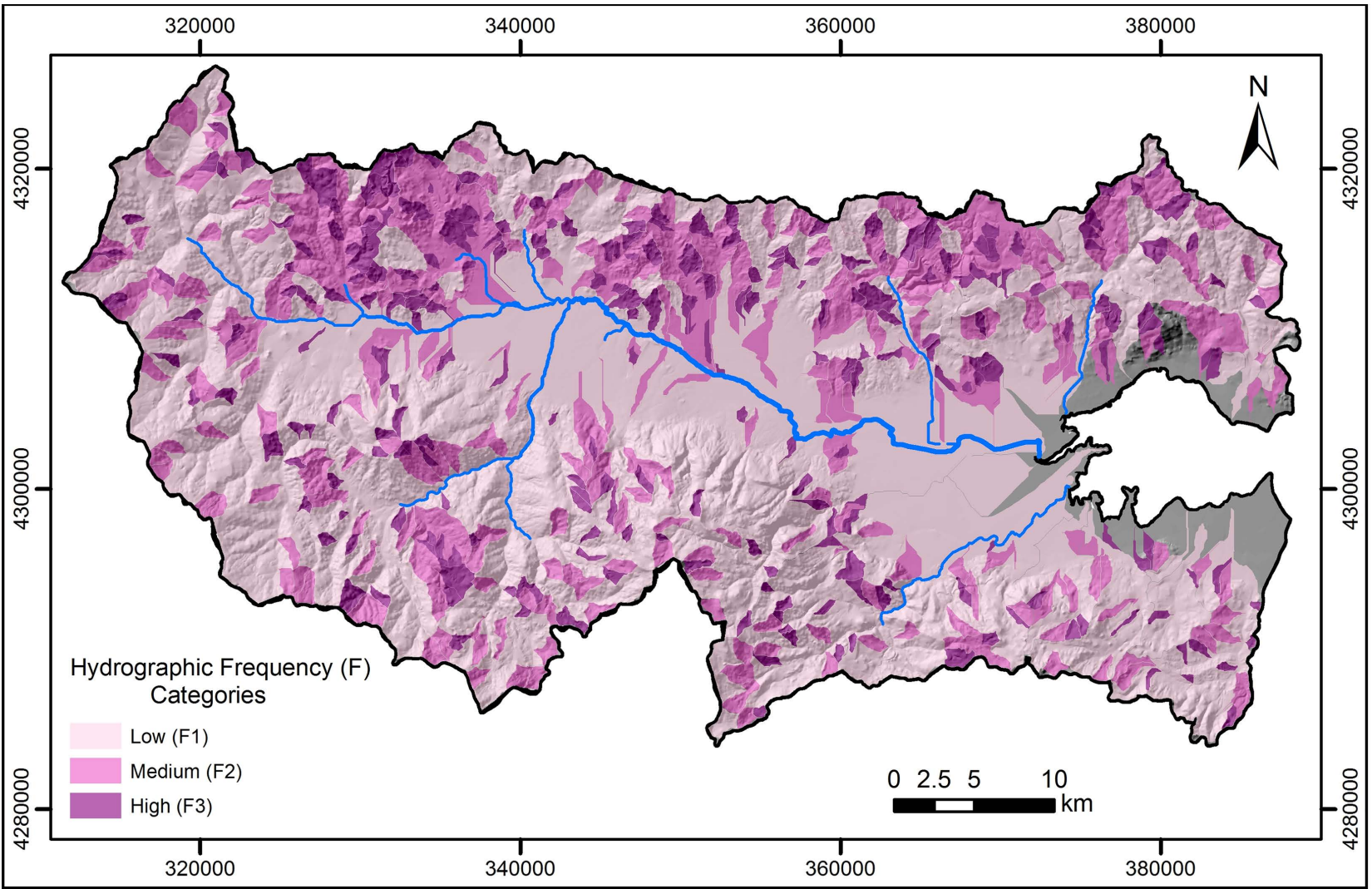

Figure 8. Classification map of the study area, based on hydrographic frequency.

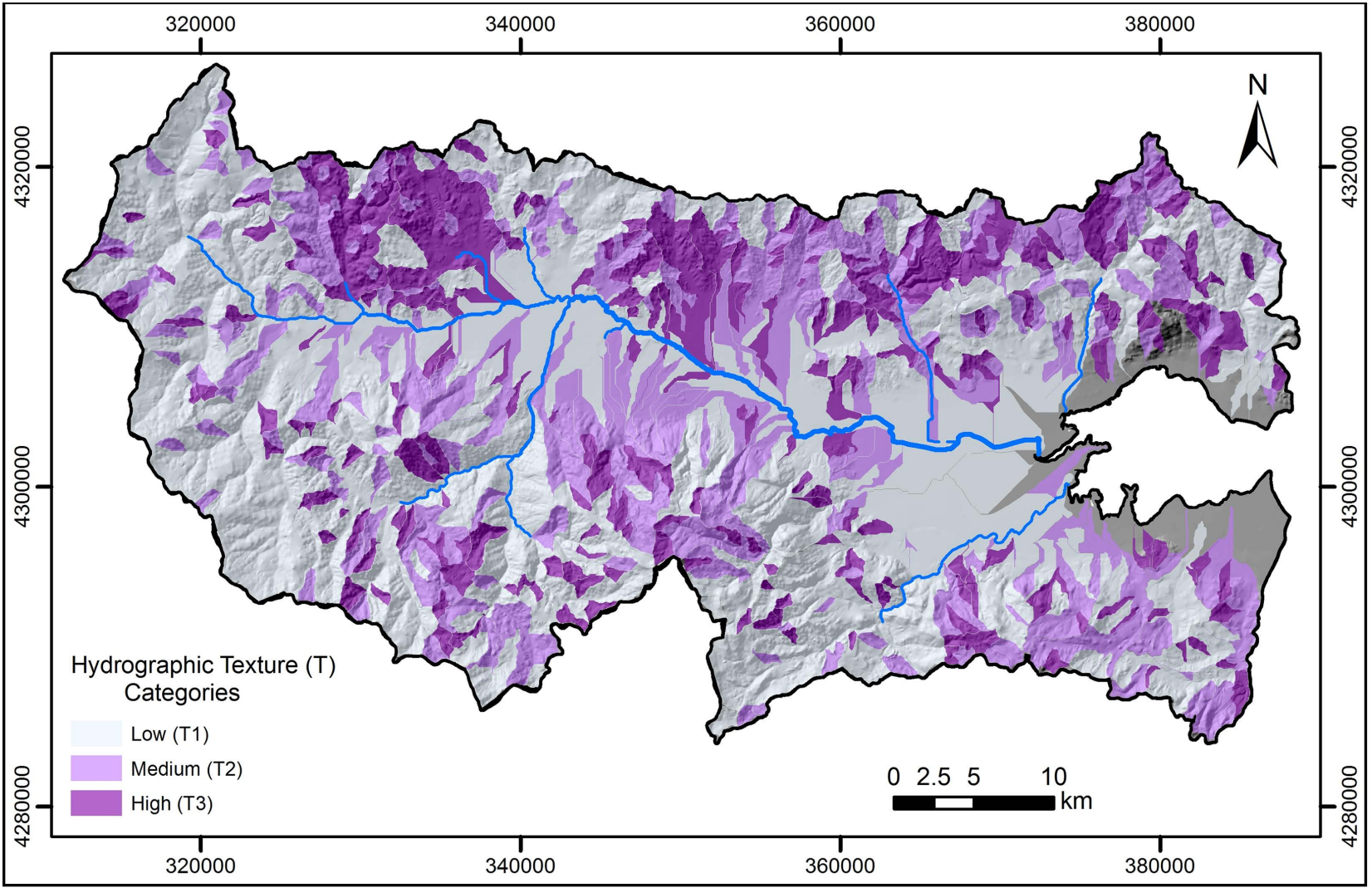

Figure 9. Classification map of the study area based on hydrographic texture. 
The combination of the two thematic maps of hydrographic density and frequency resulted in the "Map of hydrographic texture" (T). In this map the study area is classified in three categories of low (T1), medium (T2) and high (T3) hydrographic texture (Figure 9) according to Table 2 presented in paragraph 2.3.6.

\subsubsection{Rainfall Factor}

Rainfall data in Sperchios River basin were evaluated from the records of eight

Table 1. Drainage density and stream frequency description.

\begin{tabular}{|c|c|c|c|}
\hline Drainage Density (Dd) & $\mathrm{Dd}=\mathrm{Lu} / \mathrm{A}$ & Horton $(1932,1945)$ & $\begin{array}{l}\text { Dd is measured as the length of stream channels per unit area of the } \\
\text { drainage basin. }\end{array}$ \\
\hline Stream Frequency (Fs) & $\mathrm{Fs}=\Sigma \mathrm{Nu} / \mathrm{A}$ & Horton $(1932,1945)$ & $\begin{array}{l}\text { Fs is computed as the ratio between the total number of streams and } \\
\text { area of the basin. }\end{array}$ \\
\hline \multicolumn{4}{|l|}{ where, $\mathrm{u}=$ Stream order $[28]$} \\
\hline \multicolumn{4}{|c|}{$\mathrm{Nu}=$ Total no. of streams of all orders, } \\
\hline \multicolumn{4}{|c|}{$\mathrm{Lu}=$ Total stream length of all orders $(\mathrm{km})$} \\
\hline$A=$ Area of basin $\left(\mathrm{km}^{2}\right)$ & & & \\
\hline
\end{tabular}

Table 2. Categorization of the erosion vulnerability parameters.

\begin{tabular}{|c|c|c|c|c|}
\hline \multirow{2}{*}{\multicolumn{2}{|c|}{$\begin{array}{c}\text { Model Factors } \\
\text { (Vulnerability Parameters) }\end{array}$}} & \multicolumn{3}{|c|}{ Erosion Vulnerability } \\
\hline & & Low & Medium & High \\
\hline \multirow[b]{2}{*}{ 1) } & $\mathrm{L}$ & L1 & L2 & L3 \\
\hline & $\begin{array}{l}\text { Geological formations prone to erosion } \\
\text { (Lithology) }\end{array}$ & $\begin{array}{l}\text { Limestones, dolomites, } \\
\text { phyllite, etc. }\end{array}$ & $\begin{array}{l}\text { Flysch, schist, marl, sandstone, } \\
\text { conglomerate, grauwacke, etc }\end{array}$ & $\begin{array}{l}\text { Alluvial, clastic } \\
\text { sediments, etc. }\end{array}$ \\
\hline \multirow{2}{*}{ 2) } & $S$ & S1 & S2 & S3 \\
\hline & Relief gradient (Slopes) & $\mathrm{S} \leq 12 \%$ & $12 \%<\mathrm{S} \leq 35 \%$ & S > $35 \%$ \\
\hline \multirow{2}{*}{ 3a) } & Fs & F1 & F2 & F3 \\
\hline & Hydrographic Frequency & $\mathrm{F} \leq 0.62 \mathrm{~km}^{-2}$ & $0.62<\mathrm{F} \leq 1.09 \mathrm{~km}^{-2}$ & $\mathrm{~F}>1.09 \mathrm{~km}^{-2}$ \\
\hline \multirow{2}{*}{$3 b)$} & $\mathrm{Dd}$ & D1 & D2 & D3 \\
\hline & Hydrographic Density & $\mathrm{D} \leq 0.63 \mathrm{~km} / \mathrm{km}^{2}$ & $0.63<\mathrm{D} \leq 0.95 \mathrm{~km} / \mathrm{km}^{2}$ & $\mathrm{D}>0.95 \mathrm{~km} / \mathrm{km}^{2}$ \\
\hline \multirow[b]{2}{*}{ 3) } & $\mathrm{T}$ & $\mathrm{T} 1$ & $\mathrm{~T} 2$ & T3 \\
\hline & Hydrographic Texture & $\begin{array}{l}\text { Combinations of: } \\
\text { F1 and D1, D2 } \\
\text { F2 and D1 }\end{array}$ & $\begin{array}{l}\text { Combinations of: } \\
\text { F1 and D3, } \\
\text { F2 and D2 } \\
\text { F3 and D1 }\end{array}$ & $\begin{array}{l}\text { Combinations of: } \\
\text { F2 and D3 } \\
\text { F3 and D2 } \\
\text { F3 and D3 }\end{array}$ \\
\hline \multirow{2}{*}{\multicolumn{2}{|c|}{ Triggering Factor }} & Erosion Influence & & \\
\hline & & Low & Medium & High \\
\hline \multirow{2}{*}{ 4) } & $\mathbf{R}$ & R1 & R2 & R3 \\
\hline & Rainfall & $\mathrm{R} \leq 700 \mathrm{~mm}$ & $700<\mathrm{R} \leq 900 \mathrm{~mm}$ & $\mathrm{R}>900 \mathrm{~mm}$ \\
\hline \multirow{2}{*}{\multicolumn{2}{|c|}{ Competitive Factor }} & Erosion Containment & & \\
\hline & & Low & Medium & High \\
\hline \multirow[b]{2}{*}{ 5) } & $\mathrm{C}$ & $\mathrm{C} 1$ & $\mathrm{C} 2$ & $\mathrm{C} 3$ \\
\hline & Vegetation cover (Land cover) & $\begin{array}{l}\text { Sparse bushes, pasture lands } \\
\text { and areas without vegetation }\end{array}$ & Various cultivations & Forests \\
\hline
\end{tabular}


meteorological stations, which cover efficiently the surface of the study area. From the spatial and elevation distribution of the stations, the correlation between rainfall and altitude of the stations was estimated and it was found 0.6547 , which is considered good (Figure 10).

The annual rainfall was found to be between $575 \mathrm{~mm}$ and $1426 \mathrm{~mm}$, and so the total water volume of the basin was estimated in $1.687 \times 109 \mathrm{~m}^{3}$.

Most of the higher rainfall events are observed from October until December (35\% of total) and the lower between June and September (Figure 11). The average infiltration rate is about $18 \%$ and the surface runoff $12 \%$ of the total precipitation. These percentages resulted from the estimation of the hydrological equilibrium of the area (estimation of evapotranspiration based on Thornwaite method, of infiltration rate based on the area's lithology and the active porosity of the geological formations, of rainfall volume from the rainfall data).

The fourth map refers to rainfall distribution in Sperchios River basin (Figure 12). The map was created by the implementation of the linear regression equation (Figure 10), using DEM as the elevation factor (' $x$ ' factor in the equation). Rainfall is the dynamic factor of erosion and acts as an operative cause of the phenomenon on the specific soil and geomorphological characteristics (lithology, slope, hydrographic network, land cover, etc.).

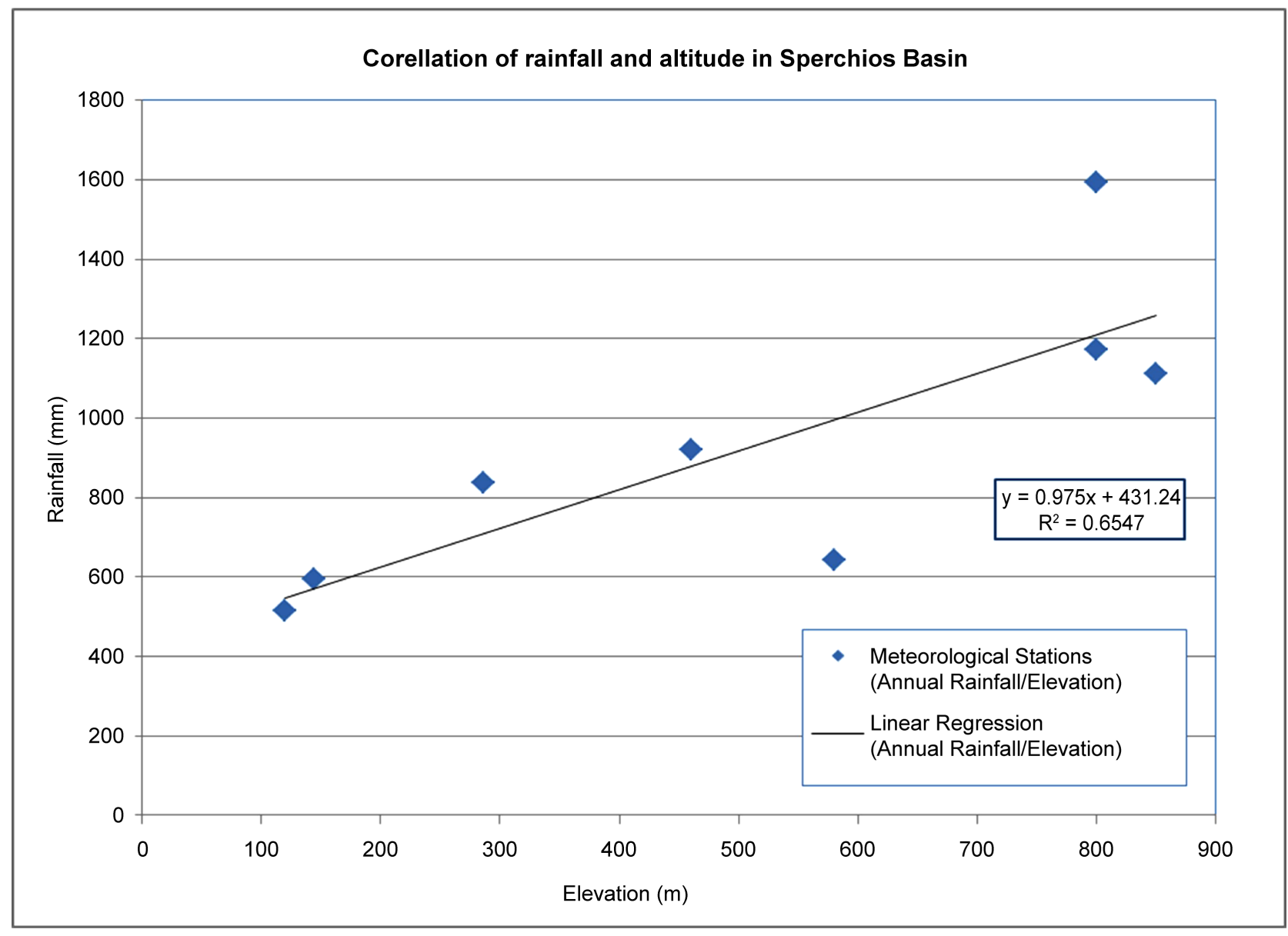

Figure 10. Correlation of annual rainfall and altitude in Sperchios River basin. 


\section{Monthly distribution of annual rainfall} in Sperchios Basin

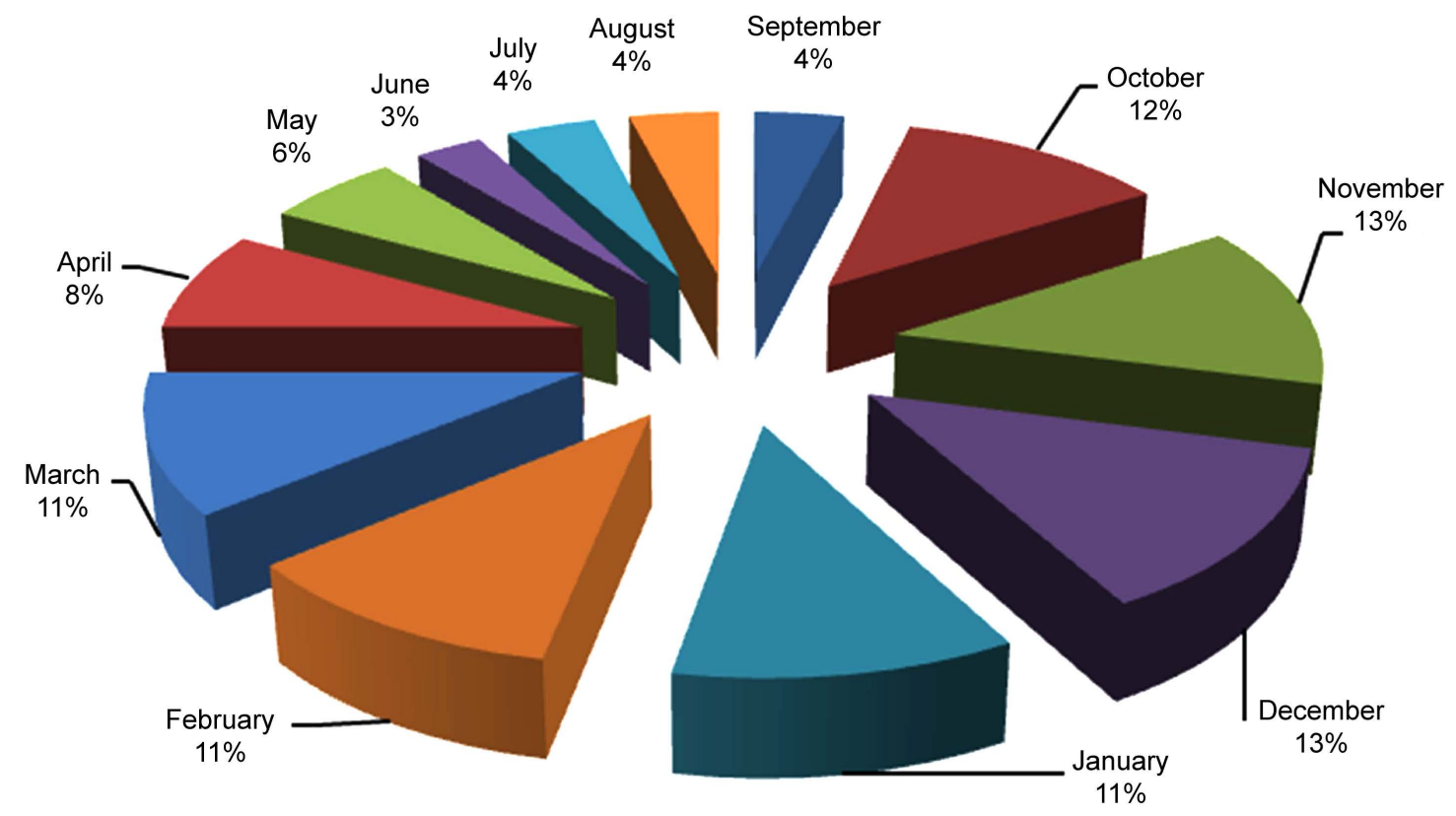

Figure 11. Monthly average rainfall in Sperchios River basin.

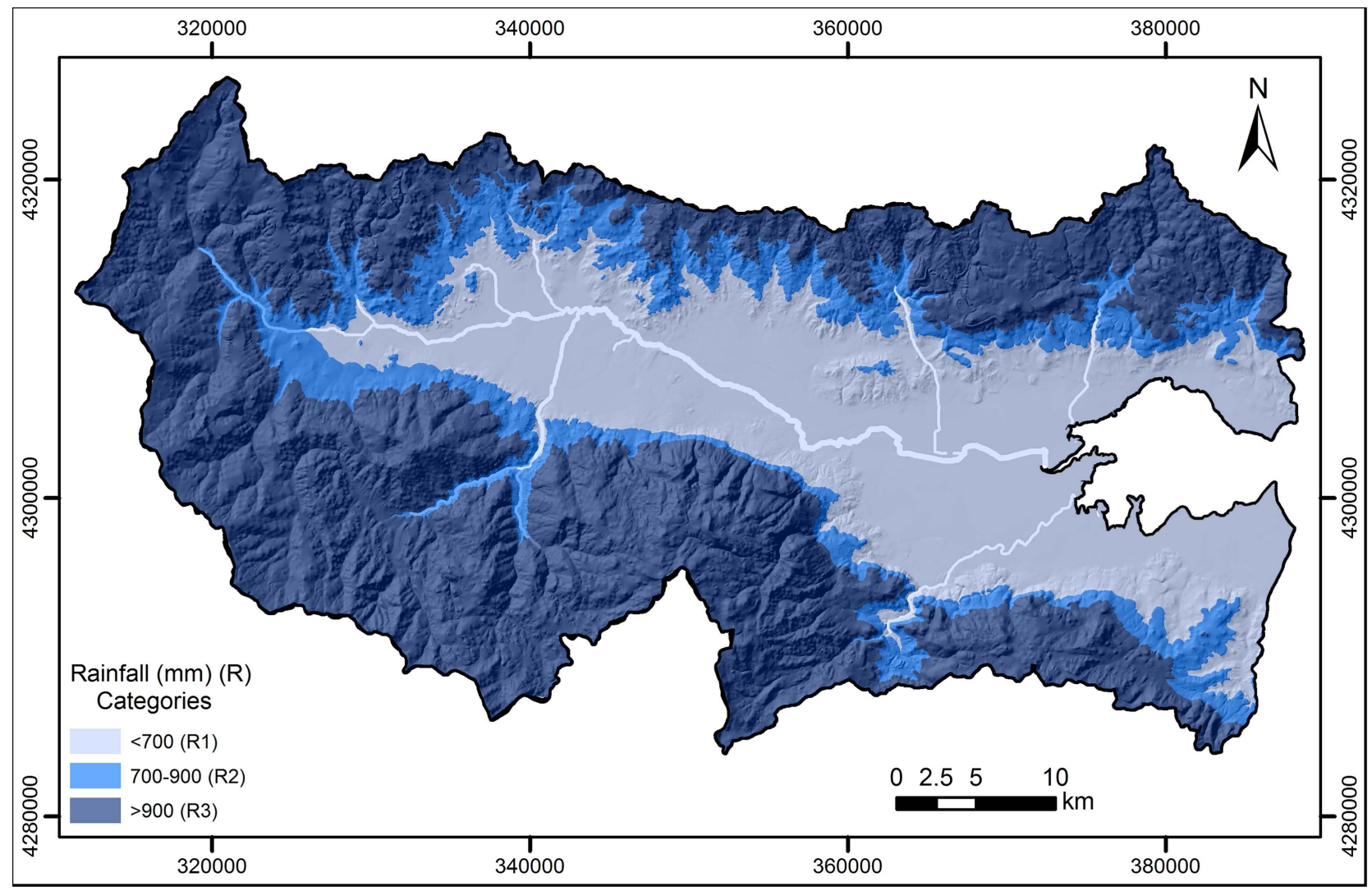

Figure 12. Classification map of the study area based on rainfall distribution. 


\subsubsection{Land Cover/Use Factor}

The next step, which refers to assessing the erosion vulnerability of the basin's formations, concerns the creation of the "Classified map of land use/cover". Land cover is a competitive and protective factor against erosion. Land use/cover data were obtained from Corine 2000, and were classified into three categories (Figure 13). The first category (C1) includes moorlands and scrublands, natural pastures, areas with sparse vegetation, urban construction, etc. Because overgrazing is associated with desertification in Mediterranean Europe, particularly in the areas prone to fire [29], it was considered that pastures (due to overgrazing) belong to the vegetation class of insufficient protection against erosion, in order to estimate the worst case scenario of soil erosion in the study area. The second category (C2) includes farmland, hard leaf vegetation, olive groves, rice paddies, vineyards, non-irrigated arable land, etc. Finally, the third category (C3) includes coniferous forests, broadleaved forests, mixed woodland, transitional woodland-shrubland, etc. As it is obvious from the above, $\mathrm{C} 1$ category provides low protection in terms of erosion, C2 medium and C3 high protection.

As shown in Figure 14, the highest percentage of land cover/use is hardleaf vegetation $(22 \%)$ and non-arable land (17\%), while the percentage of bare rocks $(0.67 \%)$ and vineyards $(0.07 \%)$ is low.

\subsubsection{Classification of Factors}

Summarizing the previous steps, Table 2 presents the categorization of the factors

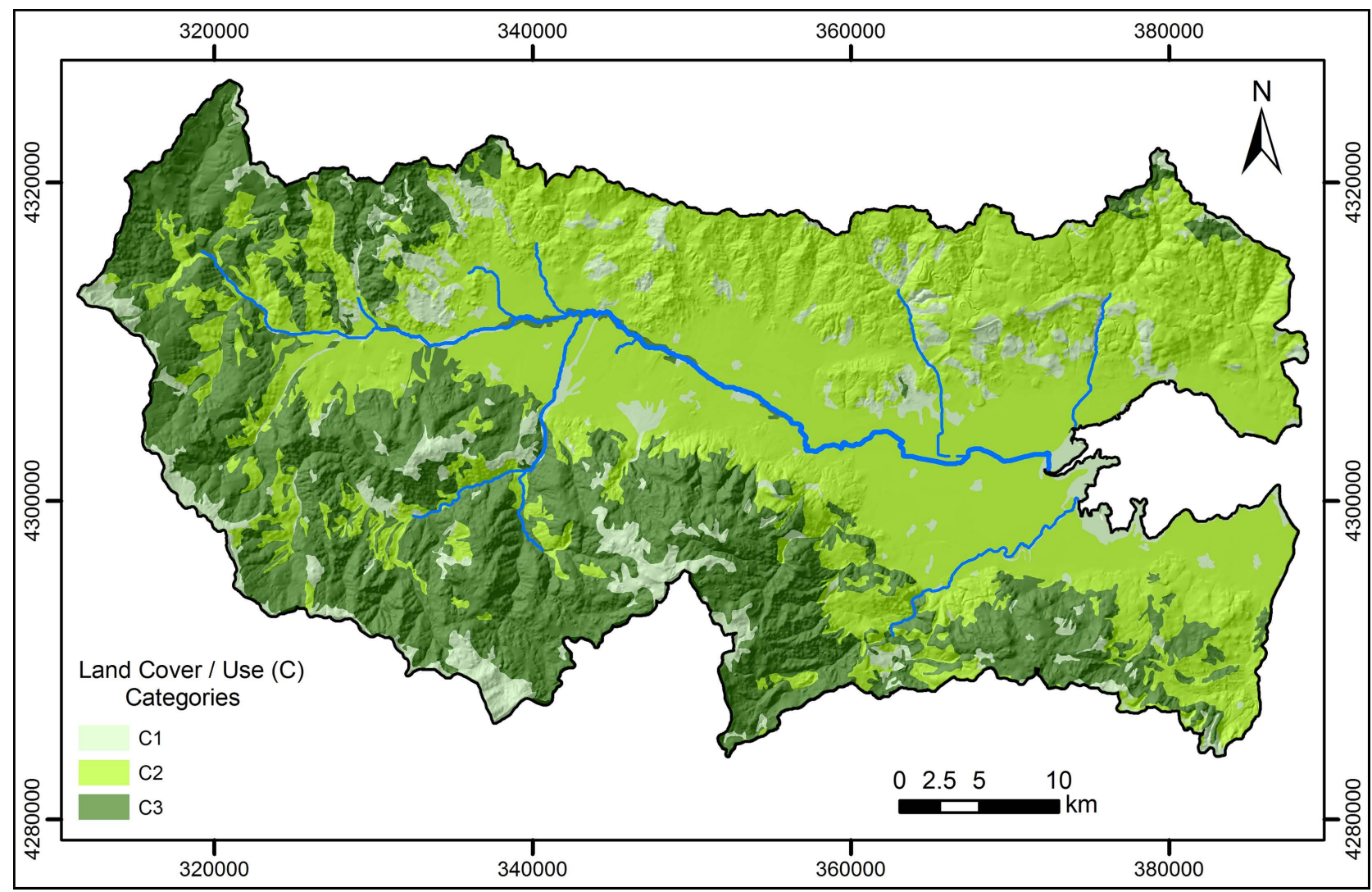

Figure 13. Classification map of the study area based on land use/cover. 


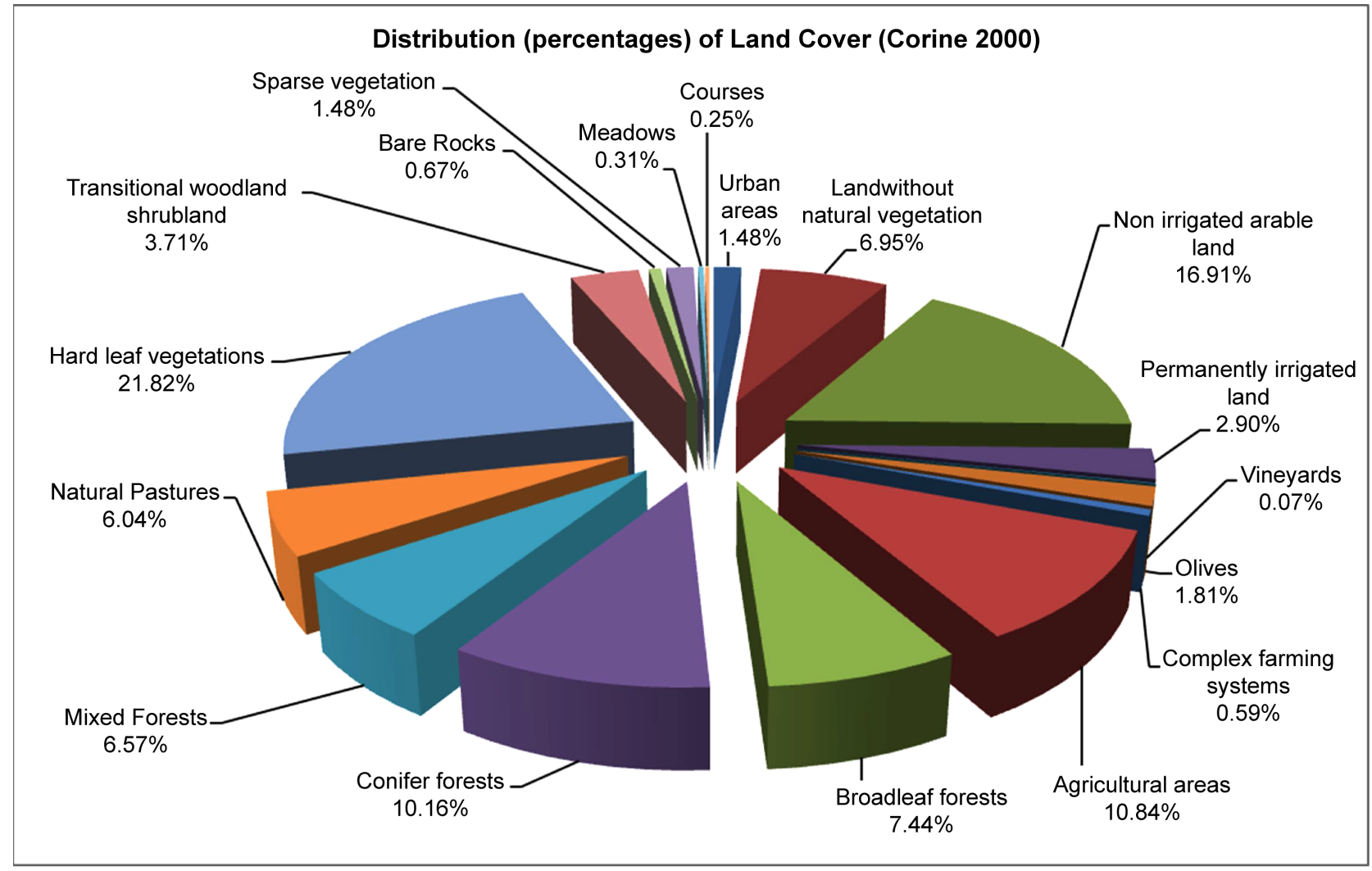

Figure 14. Land Cover distribution of Sperchios River basin.

used in order to synthesize the erosion vulnerability model of Sperchios River basin. The categorization was based on the erosion vulnerability of each parameter's attributes (by grouping them in 3 categories as described in previous paragraphs), or its effect in the phenomenon (rainfall, land cover).

\subsubsection{Synthesis of Erosion Vulnerability Factors}

For the creation of the "Erosion vulnerability map without land cover factor", weights were assigned for each factor that was previous described, such as:

a) geological formations vulnerability factor (L)

b) morphological slope factor (S)

c) hydrographic texture factor $(\mathrm{T})$

d) rainfall distribution factor $(\mathrm{R})$

Lithology was evaluated as the main/key factor that contributes to erosion. Geological formations are the source that offer the erosion material, thus this factor was considered to have the highest importance and contribution in the model (35\%). The morphological and hydrographic characteristics of the basin are also of high importance, as these factors constitute the background base for erosion to occur and in this study were considered to contribute equally in the model $(20 \%$ each). In order for erosion to take place, a triggering factor is needed and rainfall volume is the main one, especially when a hydrological basin is studied. Thus, it was considered as the second most important factor of the model (25\%). It is highly important to mention that this study is targeted in ero- 
sion caused by rainfall and not by other triggering factors (e.g. wind, snowfall and snow coverage, etc.). Furthermore, this study doesn't focus on erosion caused by extreme events (e.g. storms, floods, etc.) but mainly on the volume of rainfall an area receives throughout a year. Finally, it must be underlined, that the contributing significance of each factor in the model was evaluated by bibliographical research and the scientific opinion and experience of the authors.

The map of the erosion vulnerability of Sperchios River basin is a combination of categorized thematic maps of "bare" soil vulnerability (Eb) and land cover/use. Three categories of vulnerability were created, low (Ec1), medium (Ec2) and high (Ec3), according to Table 3 below.

The categorization of the factors (lithology, geomorphology, hydrology and vegetation) in the basin, namely the differentiation of the sub-basins based on the vulnerability of their formations, in this paper consists of three classes low, medium and high. The last category (high) estimates high soil erosion risk areas. Taking under consideration that land cover (mainly vegetation cover) is the main competitive factor of erosion, Table 3 and the map of soil vulnerability with land cover (the corresponding figureis presented and discussed in the "Results \& discussion" chapter) were created. This new map of the erosion vulnerability with land cover factor depicts the real condition of Sperchios River basin. It must be noted that Table 3 was created taking under consideration that as land cover and vegetation cover category rises the soil protection against erosion rises, thus improving its final categorization, in comparison with the one evaluated by the model (erosion vulnerability of bare soil).

\subsubsection{Sensitivity Analysis}

In order to evaluate the model's stability and reliability, 4 different scenarios of sensitivity analysis were implemented. As shown in Table 4, in the 1st scenario

Table 3. Correlation of "bare" soil vulnerability with land cover/use factor.

\begin{tabular}{cllll}
\hline \multirow{2}{*}{$\begin{array}{c}\text { Soil Erosion Vulnerability with } \\
\text { Vegetation Cover (Ec) }\end{array}$} & \multicolumn{4}{l}{ Erosion Vulnerability of Bare Soil (Eb) } \\
\cline { 3 - 5 } & $\mathrm{C} 1$ & $\mathrm{~Eb} 1$ & $\mathrm{~Eb} 2$ & $\mathrm{Eb3}$ \\
\hline \multirow{2}{*}{ Land Cover (C) } & $\mathrm{C} 2$ & $\mathrm{Ec1}$ & $\mathrm{Ec2}$ & $\mathrm{Ec3}$ \\
& $\mathrm{C} 3$ & $\mathrm{Ec1}$ & $\mathrm{Ec1}$ & $\mathrm{Ec} 2$ \\
& & & & Ec2 \\
\hline
\end{tabular}

Table 4. Sensitivity analysis scenarios.

\begin{tabular}{ccc}
\hline \multirow{2}{*}{ SCENARIOS } & \multicolumn{2}{c}{ FACTORS } \\
\cline { 2 - 3 } & LITHOLOGY & RAINFALL \\
\hline 1 & $+3 \%$ & $-3 \%$ \\
2 & $+5 \%$ & $-5 \%$ \\
3 & $-3 \%$ & $+3 \%$ \\
4 & $-5 \%$ & $+5 \%$ \\
\hline
\end{tabular}


the contribution of lithology factor in the model was increased by $3 \%$, while the rainfall factor was reduced by $3 \%$. In the 2 nd scenario lithology factor was increased by $5 \%$ and the rainfall factor reduced by $5 \%$. Scenarios 3 and 4 are the reverse ones of 1 and 2 correspondingly.

Based on the results of the 4 scenarios, area cover and percentage for each new erosion susceptibility category was calculated and compared with the model's corresponding values (Table 5).

The previous table presents the area extent (in $\mathrm{km}^{2}$ ) that each category, of the model and the four scenarios, covers. The same extent is shown also in percentage. Finally, the difference between the extents of each category of the four scenarios with those of the model is presented.

\section{Results and Discussion}

Many models are based on assigning weights on the specified factors. The proposed model of this paper is relatively simple and easily applicable and in addition is capable of altering the weights of the factors, in each sub-basin, according to which ones (factors) exceed the rest and enhance the vulnerability of the

Table 5. Results of sensitivity analysis scenarios.

\begin{tabular}{|c|c|c|c|}
\hline $\begin{array}{l}\text { EROSION VULNERABILITY } \\
\text { CATEGORY }\end{array}$ & $\begin{array}{l}\text { AREA } \\
\left(\mathrm{km}^{2}\right)\end{array}$ & $\begin{array}{c}\text { PERCENTAGE } \\
(\%)\end{array}$ & $\begin{array}{c}\text { DIFFERENCE } \\
(\%)\end{array}$ \\
\hline \multicolumn{4}{|c|}{ MODEL } \\
\hline 1 & 226.5 & 11.2 & - \\
\hline 2 & 1077.7 & 53.2 & - \\
\hline 3 & 722.1 & 35.6 & - \\
\hline \multicolumn{4}{|c|}{ SCENARIO 1} \\
\hline 1 & 163.8 & 8.1 & 3.1 \\
\hline 2 & 1205.5 & 59.5 & -6.3 \\
\hline 3 & 657.0 & 32.4 & 3.2 \\
\hline \multicolumn{4}{|c|}{ SCENARIO 2} \\
\hline 1 & 163.8 & 8.1 & 3.1 \\
\hline 2 & 1205.5 & 59.5 & -6.3 \\
\hline 3 & 657.0 & 32.4 & 3.2 \\
\hline \multicolumn{4}{|c|}{ SCENARIO 3} \\
\hline 1 & 208.8 & 10.3 & 0.9 \\
\hline 2 & 912.0 & 45.0 & 8.2 \\
\hline 3 & 905.5 & 44.7 & -9.1 \\
\hline \multicolumn{4}{|c|}{ SCENARIO 4} \\
\hline 1 & 240.0 & 11.8 & -0.7 \\
\hline 2 & 880.8 & 43.5 & 9.7 \\
\hline 3 & 905.5 & 44.7 & -9.1 \\
\hline
\end{tabular}


formations (lithological, geomorphological), which ones enhance the soil material transportation (slopes) and which ones the protection against erosion (vegetation). Additionally, this model can be further developed by including more factors related to soil erosion, in a simple way as this paper indicates where the hydrographic texture was taken under consideration, which is a result of neotectonic activity as well as of precipitation.

The applied methodology, both by overestimating or underestimating, produces acceptable and significant results and allows the qualitative detection of the most sensitive areas to soil erosion, making it an important tool for territorial and environmental management.

As it was discussed above, the "Map of Sperchios River Basin Erosion Vulnerability without Land Cover Factor" that was created by the model of this study is presented in Figure 15.

As it is revealed from this map, sites, with the highest erosion vulnerability, are found, in the parts of the basin, which are covered by highly erodible formations, have high morphological gradients, are characterized by high hydrographic texture and receive the highest rainfall volumes. The extents of the sites with low, medium and high vulnerability are presented in Figure 16. According to this figure, the largest extent of the basin $\left(1077.7 \mathrm{~km}^{2}\right)$ is covered by formations with medium erosion vulnerability (53.2\%). Sites of higher erosion vulnerability occupy the $35.6 \%$ of the whole surface of the basin $\left(722.1 \mathrm{~km}^{2}\right)$.

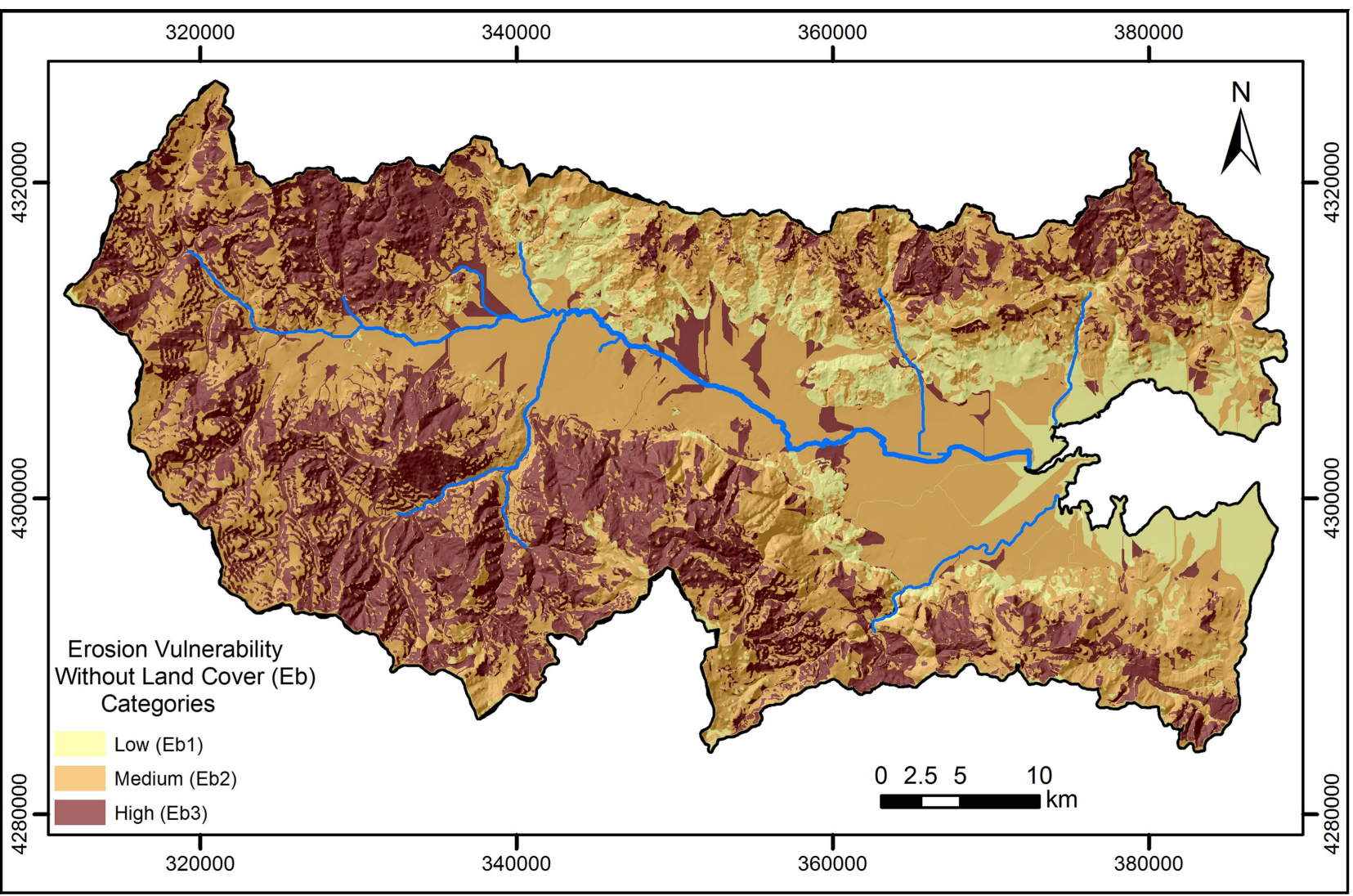

Figure 15. Classification map of the study area according to erosion vulnerability (without land cover factor). 
The final "Map of Sperchios River Basin Erosion Vulnerability" that was created by the combination of categorized thematic maps of "bare" soil vulnerability $(\mathrm{Eb})$ and land cover/use is presented in Figure 17.

Figure 18 presents the extents of the three categories derived from the map of Figure 17. According to this figure the erosion vulnerability for the low category (Ec1) the values in surface extension and percent are $1201.3 \mathrm{~km}^{2}$ and $59.1 \%$

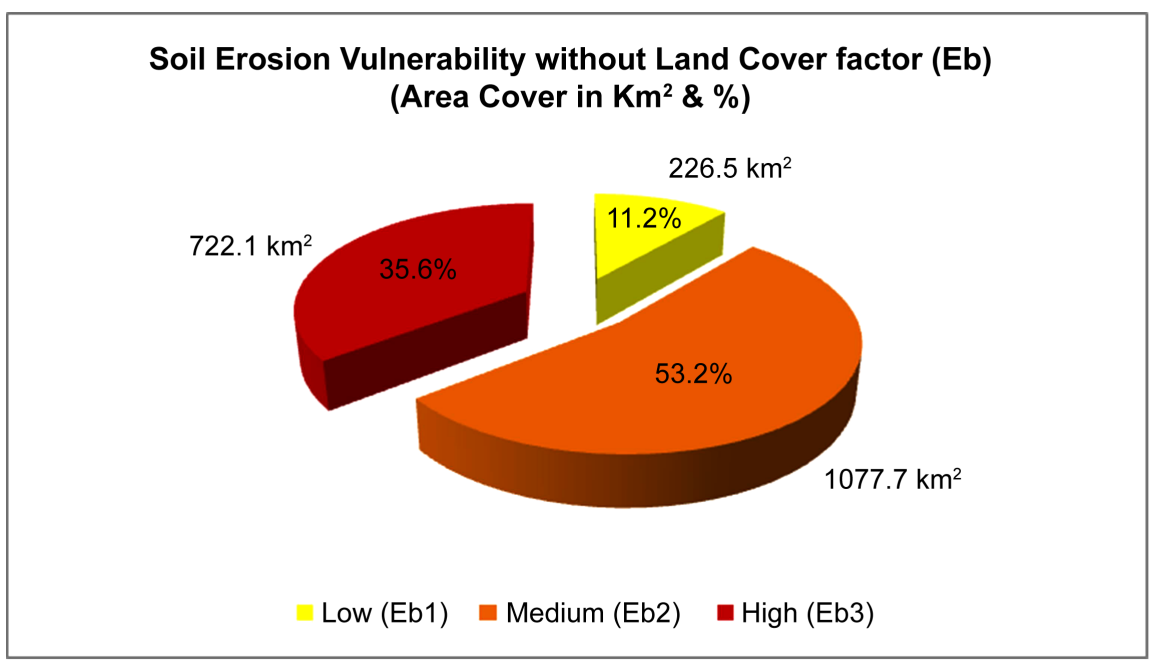

Figure 16. Area's extents according to their erosion vulnerability classification (without land cover) in $\mathrm{km}^{2}$ and $\%$.

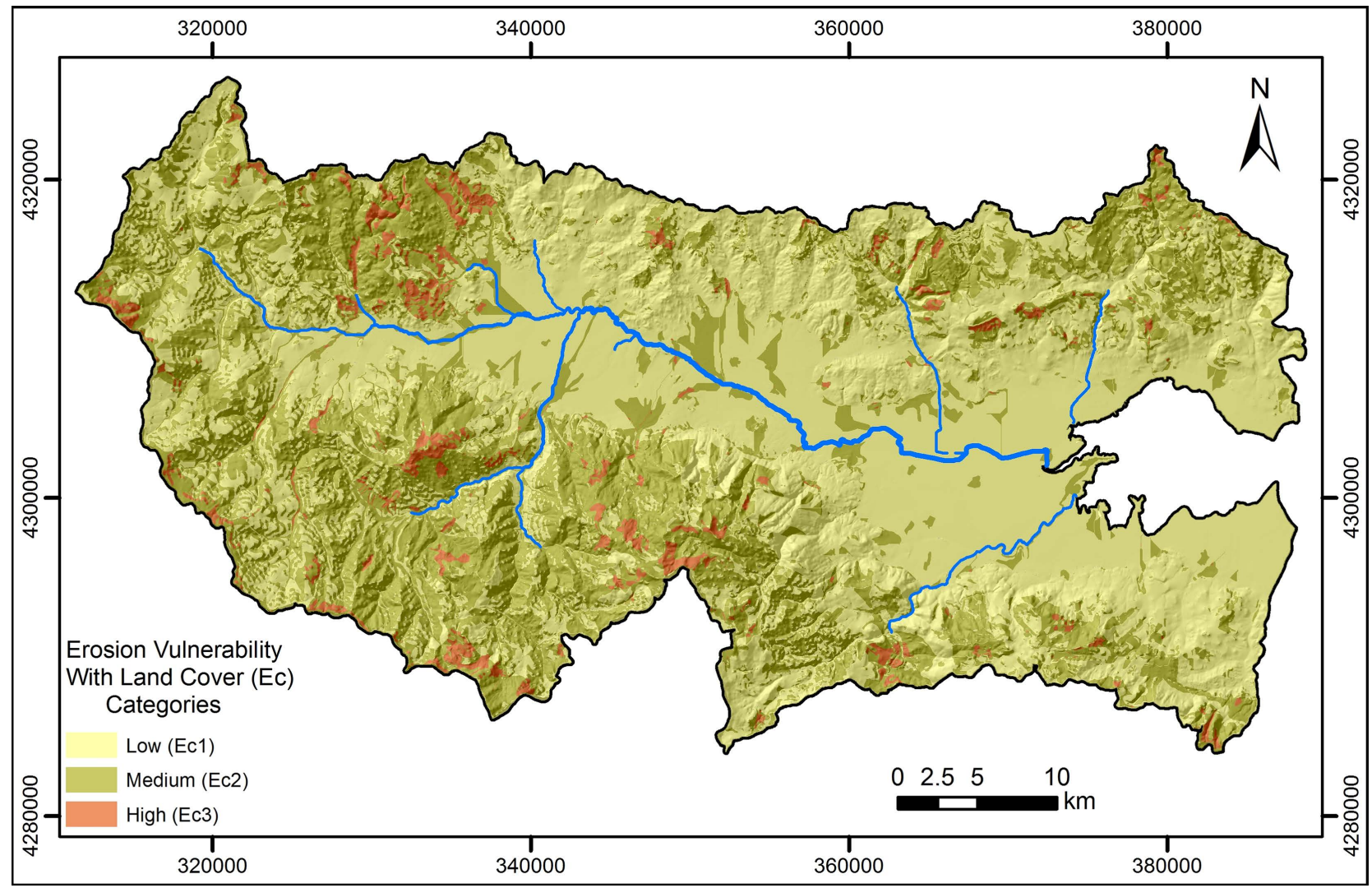

Figure 17. Classification map of the study area, according to their erosion vulnerability (with land cover factor). 
respectively, while for the medium one (Ec2) these values are $764.9 \mathrm{~km}^{2}$ and $37.7 \%$. Finally, for the high category (Ec1), the surface extension and percent are $65 \mathrm{~km}^{2}$ and $3.2 \%$ correspondingly.

Taking into account the land cover/use factor, a drastic reduction of the Ec2 and $\mathrm{Ec} 3$ categories is obvious.

Therefore, formations, whose vulnerability characterization was changed by co-evaluating the land cover factor, are mainly in medium and high vulnerability category (Figure 19).

Specifically, the area's extents that changed category (Figure 20), as to their erosion vulnerability classification by co-evaluation of the land cover factor, are

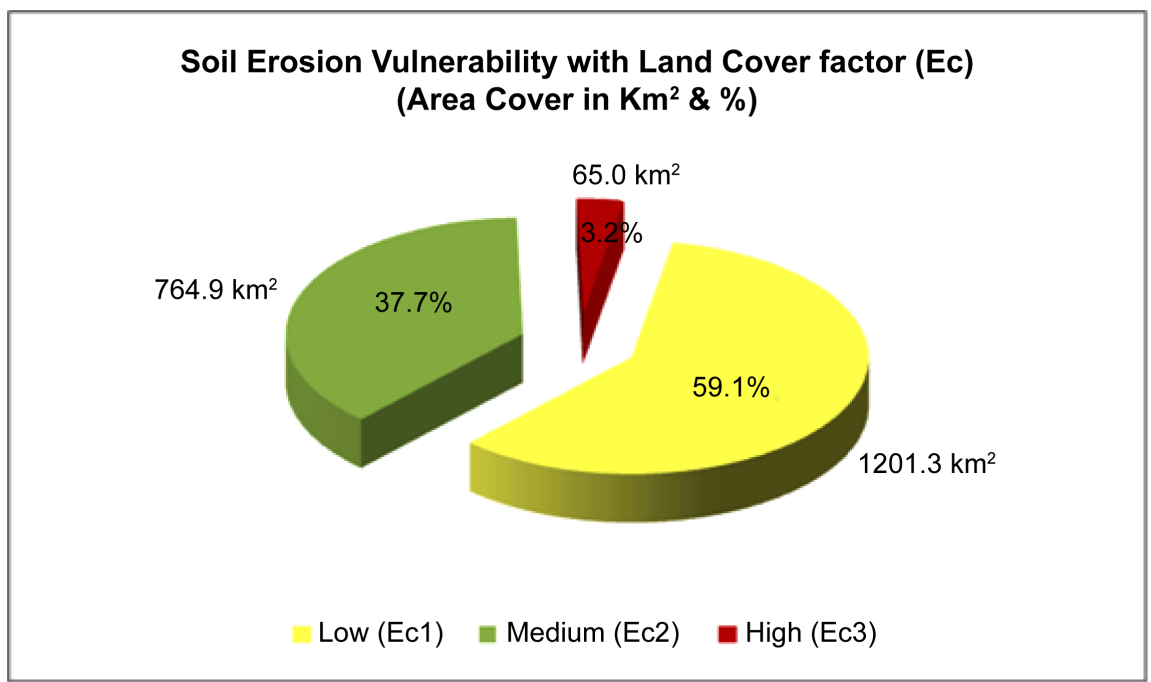

Figure 18. Area's extents, according to their erosion vulnerability classification (with land cover), in $\mathrm{km}^{2}$ and $\%$.

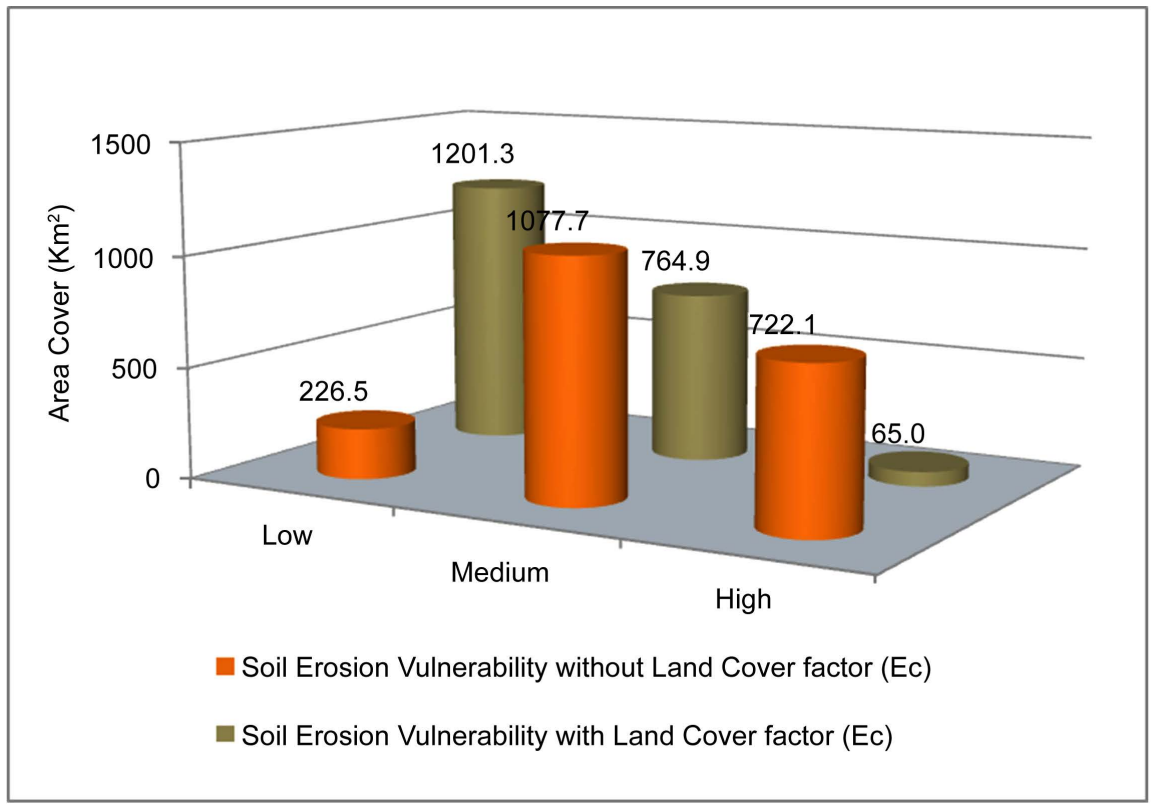

Figure 19. Area's extents, according to their erosion vulnerability classification, with and without land cover in $\mathrm{km}^{2}$. 
from medium to low category $969.9 \mathrm{~km}^{2}$ (47.7\%) and from high to medium $657.1 \mathrm{~km}^{2}(32.4 \%)$, while the area that has not changed category is $404.2 \mathrm{~km}^{2}$ (19.9\%).

Finally, based on the results of the sensitivity analysis scenarios, the model is characterized as highly stable and reliable, because the highest divergence (area cover difference) that was estimated is below $10 \%$ (Figure 21, Figure 22). The highest area cover difference (compared with the model) is found in the 2nd erosion vulnerability category of the 4 th scenario $(9.7 \%)$ and the second highest in the 3rd category of both scenarios $3 \& 4(-9.1 \%)$, while scenarios $1 \& 2$ show the same results (area cover differences compared with the model) in all 3 categories (Figure 21, Figure 22). Figure 22 depicts the difference percentages per class, compared to the model, for every sensitivity analysis scenario, stating clearly that none exceeds the limit of $10 \%$ and verifying thus the model's stability.

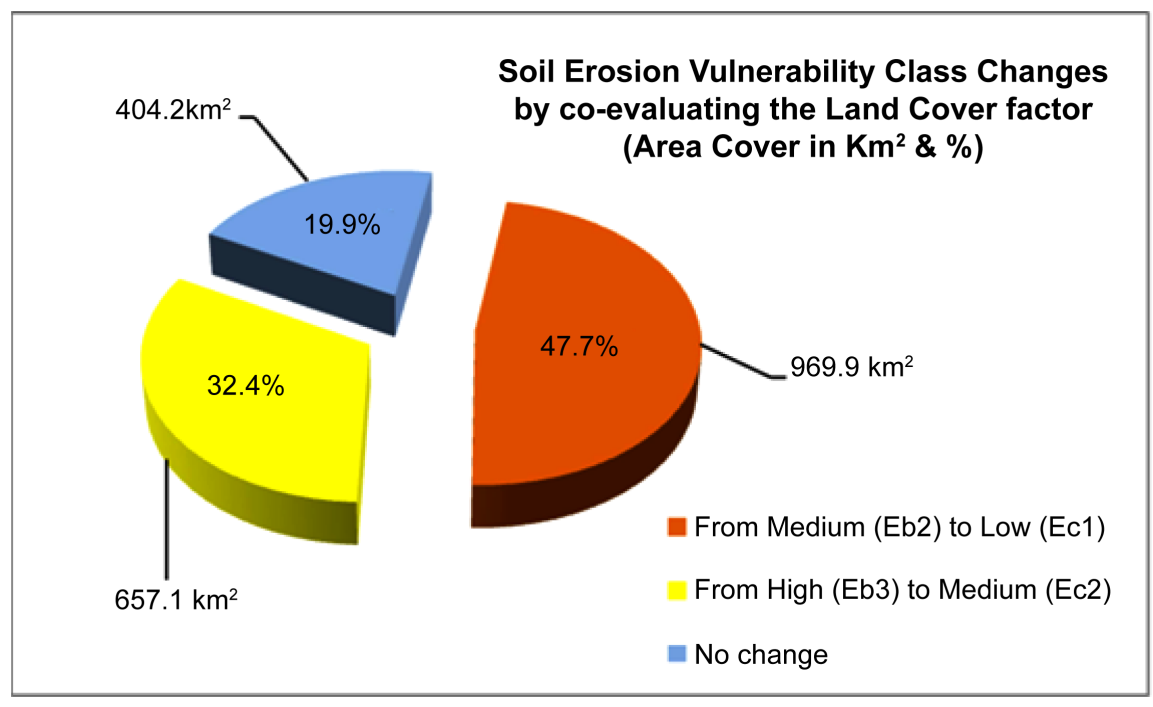

Figure 20. Area's extents that changed category, as to their erosion vulnerability classification, by co-evaluation of the land cover factor.

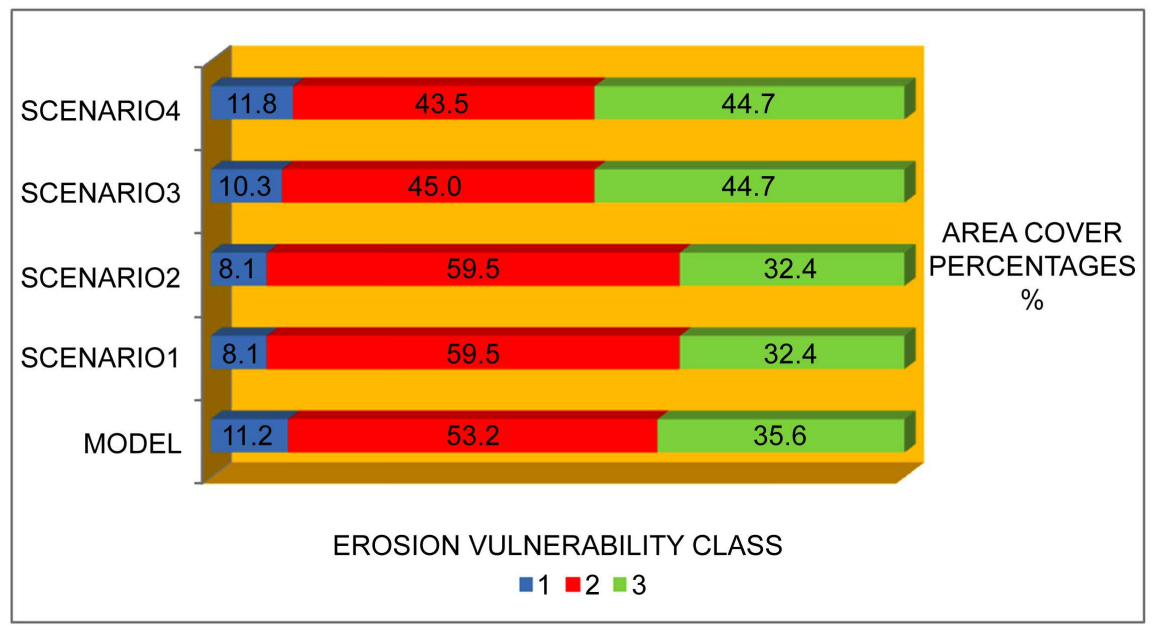

Figure 21. Percentages of area coverage, per erosion vulnerability category, for each sensitivity analysis scenario. 


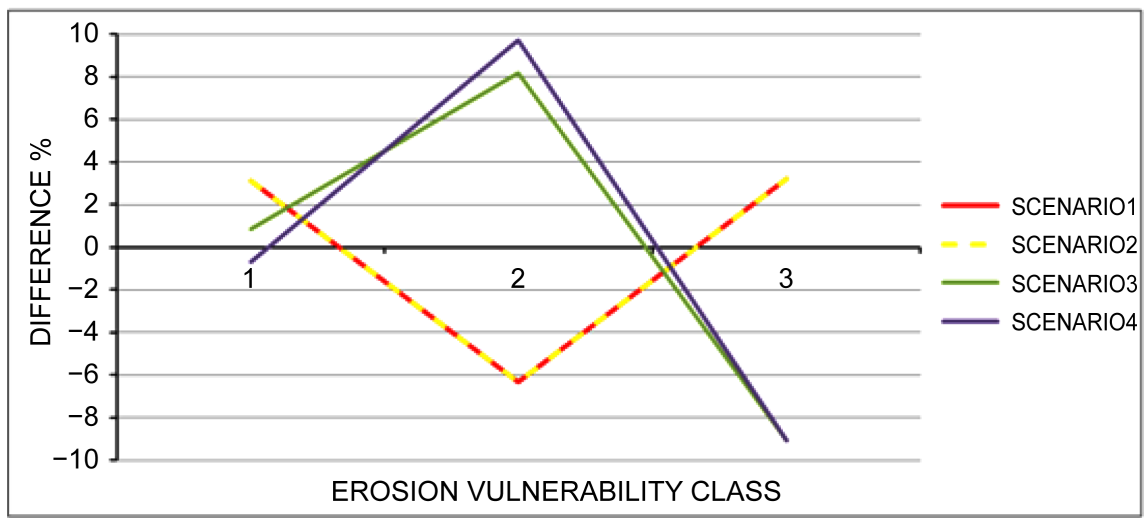

Figure 22. Differences (\%) of area coverage, per erosion vulnerability class for each sensitivity analysis scenario.

To sum up, from the methodology applied, in processing and analyzing the erosion vulnerability that affects the formations of Sperchios River basin, the following conclusions emerged:

- Areas of low vulnerability include mainly formations resistant to erosion (e.g. limestones) with low gradients (slopes) and low annual rainfall volumes. In this category belong formations with high infiltration rates, high permeability and thus low surficial runoff, such as carbonate rocks, which are fractured and highly karstified and with discontinuities and cracks, as well as formations with low infiltration, such as schists.

- Areas characterized by high vulnerability are mostly found in higher altitudes with high slope values and increased annual rainfall. The geological formations that are more susceptible to erosion in these sites belong to hard soil and soft rocks formations, like flysch sediments and Neogene deposits. In this category belong formations with medium infiltration rates, such as Neogene sediments and the weathering mantle, which can become saturated by long-term rainfalls and thus loosen and erode easily.

The applied vulnerability analysis covers the first stage, which does not take into account land cover or other land uses in the area. It relies solely on coevaluation of lithological-hydrogeological, morphological, hydrological and rainfall characteristics of the area.

The estimations and conclusions derived from this part of the survey provide information on unfavorable conditions, in extreme events, such as forest fires, destruction of crops etc. Furthermore, in the second stage of the method, in order to better access the actual and physical conditions of the area, the land cover and uses of the basin were taken into account, as land cover/use is a competitive factor to erosion.

From the final map it was concluded that the protective effect of land cover leads to demotion of vulnerability categories in terms of erosion respectively, compared with those that were assessed in the first stage of the model (without taking into account the factor of land cover/use). Thus, the majority of the areas belonging to high category in the vulnerability map of "bare" soil (Eb), changed 
to medium category in the erosion vulnerability map with land cover (Ec), i.e. $657.1 \mathrm{~km}^{2}$ (32.4\%). Respectively, medium vulnerability category that changed into low, cover $969.9 \mathrm{~km}^{2}$ (47.7\%).

In summary, in the final vulnerability map with the factor of land cover, the largest area belongs to low vulnerability category $\left(1201.3 \mathrm{~km}^{2}, 59.1 \%\right)$. Medium class vulnerability is second in extent $\left(764.9 \mathrm{~km}^{2}, 37.7 \%\right)$. In high vulnerability category there are very small scattered areas throughout the basin.

Finally, taking under consideration the applied sensitivity analysis the model can be characterized as sufficiently stable and reliable. From the 4 scenarios implemented the highest differentiation observed was under $10 \%$, which is considered to be inside the acceptable limits.

\section{Conclusions}

In this paper, as mentioned before, an attempt is made on spatial estimation of soil erosion in large mountainous catchments of Mediterranean type like Sperchios River, using the MCE method. For this purpose, an evaluation based on GIS was adopted. The applied methodology comprises qualitative analysis. The application of MCE in Sperchios River catchment, aiming at spatial vulnerability assessment of the geological formations, offers in addition valuable assessment of the expected spatial distribution of soil erosion.

This method approximates sufficiently the real conditions of erodibility in Sperchios basin, while the results correspond highly to the ones of other similar methods applied to the area [30].

The proposed method, described in this paper, is simple to use and can be implemented in all basins regardless of their extent. The application of this methodology, for spatial assessment of the formations' erosion vulnerability, with co-evaluation of selected factors, can constitute the basic research for exploring places in order to carry out technical projects. It can also help proper environmental planning and reduction of economic and social consequences caused by soil erosion in the study region.

Finally, it must be mentioned that this methodology is based on a local model that can be used (as it is or with suitable adjustments) in Mediterranean hydrological basins with same or similar geological formations.

\section{References}

[1] Beskow, S., Mello, C.R., Norton, L.D., Curi, N., Viola, M.R. and Avanzi, J.C. (2009) Soil Erosion Prediction in the Grande River Basin, Brazil, Using Distributed Modeling. Catena, 79, 49-59.

[2] Zhang, Z.-H., Gang, H.U. and Jian, N.I. (2013) Effects of Topographical and Edaphic Factors on the Distribution of Plant Communities in Two Subtropical Karst Forests, Southwestern China. Journal of Mountain Science, 10, 95-104. https://doi.org/10.1007/s11629-013-2429-7

[3] Voogd, H. (1983) Multicriteria Evaluation for Urban and Regional Planning. Pion, London.

[4] Pereira, J.M.C. and Duckstein, L. (1993) A Multiple Criteria Decision-Making Approach to GIS-Based Land Suitability Evaluation. International Journal of Geo- 
graphical Information Systems, 7, 407-424.

https://doi.org/10.1080/02693799308901971

[5] Heywood, I., Oliver, J. and Tomlinson, S. (1995) Building an Exploratory MultiCriteria Modeling Environment for Spatial Decision Support. In: Fisher, P., Ed., Innovations in GIS 2, Taylor \& Francis, Bristol, 127-136.

[6] Malczewski, J. (1996) A GIS-Based Approach to Multiple Criteria Group DecisionMaking. International Journal of Geographical Information Systems, 10, 955-971. https://doi.org/10.1080/02693799608902119

[7] Tecle, A. and Yitayew, M. (1990) Preference Ranking of Alternative Irrigation Technologies Via a Multicriterion Decision Making Procedure. Transactions of the ASAE, 33, 1509-1517. https://doi.org/10.13031/2013.31502

[8] Ceballos-Silva, A. and López-Blanco, J. (2003) Evaluating Biophysical Variables to Identify Suitable Areas for Oat in Central Mexico: A Multi-Criteria and GIS Approach. Agriculture Ecosystem and Environment Journal, 95, 371-377.

[9] Ceballos-Silva, A. and Lopez-Blanco, J. (2003) Delineation of Suitable Areas for Crops Using a Multi-Criteria Evaluation Approach and Land Use/Cover Mapping: A Case Study in Central Mexico. Agricultural Systems, 77, 117-136.

[10] Leskinena, P. and Kangas, J. (2005) Multi-Criteria Natural Resource Management with Preferentially Dependent Decision Criteria. Journal of Environmental Management, 77, 244-251.

[11] Bello-Pineda, J., Ponce-Hernández, R. and Liceaga-Correa, M.A. (2006) Incorporating GIS and MCE for Suitability Assessment Modelling of Coral Reef Resources. Environmental Monitoring and Assessment, 114, 225-256. https://doi.org/10.1007/s10661-006-4628-y

[12] Hajkowicz, S. and Higgins, A. (2006) A Comparison of Multiple Criteria Analysis Techniques for Water Resource Management. European Journal of Operational Research, 184, 255-265.

[13] Marinos, P., Plessas, S. and Valadaki-Plessa, K. (1998) Thematic Maps Concerning Erosion Vulnerability Estimation and Sediment Production in Attica Prefecture. Proceedings of 4th Greek Geographical Conference, Athens, 584-616.

[14] Alexouli Livaditi, A. (1999) Quantitative Geomorphological Study of Eurotas River Drainage Network (Greece). 5th Hellenic Geographical Conference, Athens.

[15] Maroukian, H., Gaki-Papanastassiou, K., Pavlopoulos, K. and Zamani, A. (1995) Comparative Geomorphological Observations in the Kalamas Delta in Western Greece and the Sperkhios Delta in Eastern Greece. Rapport Commission International Mer Méditerranée, 34, 110.

[16] Psomiadis, E. (2010) Research of Geomorphological and Environmental Changes in Sperchios River Hydrological Basin Using New Technologies. PhD Thesis, Agricultural University of Athens, Athens.

[17] Kallergis, G., Koch, K.E. and Nicolaus, H.J. (1970) Geological Map of Greece, Sheet “Karpenision”, Scale 1:50.000. IGME Publications.

[18] Kallergis, G., Koch, K.E. and Nicolaus, H.J. (1970) Geological Maps of Greece, Sheet "Sperchias", Scale 1:50.000. IGME Publications.

[19] Marinos, G., Anastopoulos, I., Maratos, G., Melidonis, N. and Andronopoulos, V. (1957) Geological Maps of Greece, Sheet “Anavra”, Scale 1:50.000. IGME Publications.

[20] Marinos, G., Anastopoulos, I., Maratos, G., Melidonis, N. and Andronopoulos, V. (1963) Geological Maps of Greece, Sheet "Stylis", Scale 1:50.000. IGME Publications.

[21] Marinos, G., Anastopoulos, I., Maratos, G., Melidonis, N. and Andronopoulos, V. (1962) Geological Maps of Greece, Sheet "Leontarion", Scale 1:50.000. IGME Publications.

[22] Marinos, G., Anastopoulos, I., Maratos, G., Melidonis, N., Andronopoulos, V. and 
Papastamatiou, I. (1967) Geological Maps of Greece, Sheet "Lamia”, Scale 1:50.000. IGME Publications.

[23] Papastamatiou, I., Tataris, A., Vetoulis, D., Katsikatsos, G., Lalexos, N. and Eleutheriou, A. (1962) Geological Maps of Greece, Sheet “Amfikleia”, Scale 1:50.000. IGME Publications.

[24] Papastamatiou, I., Tataris, A., Vetoulis, D., Mpornovas, I. and Xristodoulou, G. (1960) Geological Maps of Greece, Sheet "Amfissa”, Scale 1:50.000. IGME Publications.

[25] Livaditi-Alexouli, A., Livaditis, G. and Likouki, E. (2002) Evaluation of Erosion Vulnerability of Geological Formations and Sediment Production in Lesvos Island, Greece. 6th Greek Geographical Conference, Thessaloniki.

[26] Horton, R.E. (1932) Drainage Basin Characteristics. American Geophysical Union Transactions, 13, 348-352. https://doi.org/10.1029/TR013i001p00350

[27] Horton, R.E. (1945) Erosional Development of Streams and Their Drainage Basins; Hydrophysical Approach to Quantitative Morphology. Geological Society of America Bulletin, 56, 275-370. https://doi.org/10.1130/0016-7606(1945)56[275:EDOSAT]2.0.CO;2

[28] Strahler, A.N. (1964) Quantitative Geomorphology of Drainage Basins and Channel Networks. In: Handbook of Applied Hydrology, Section 4 II, McGraw Hill Book Company, New York.

[29] Papanastasis, V.P. (2000) Land Degradation Caused by Overgrazing and Wildfires and Management Strategies to Prevent and Mitigate Their Effects. In: Enne, G., Zanolla, Ch. and Peter, D., Eds., Desertification in Europe: Mitigations Strategies, Land-Use Planning, European Commission, EUR 19390, Luxembourg, 187-198.

[30] Sigalos, G., Loukaidi, V., Dasaklis, S. and Alexouli-Livaditi, A. (2010) Assessment of the Quantity of the Material Transported Downstream of Sperchios River, Central Greece. Bulletin of the Geological Society of Greece, 42, 737-745.

Submit or recommend next manuscript to SCIRP and we will provide best service for you:

Accepting pre-submission inquiries through Email, Facebook, LinkedIn, Twitter, etc. A wide selection of journals (inclusive of 9 subjects, more than 200 journals) Providing 24-hour high-quality service User-friendly online submission system Fair and swift peer-review system Efficient typesetting and proofreading procedure Display of the result of downloads and visits, as well as the number of cited articles Maximum dissemination of your research work

Submit your manuscript at: http://papersubmission.scirp.org/

Or contact ojg@scirp.org 